\title{
Machine learning prioritizes synthesis of primaquine ureidoamides with high antimalarial activity and attenuated cytotoxicity
}

Jurica Levatić $^{\mathrm{a}, \mathrm{b}}$, Kristina Pavić ${ }^{\mathrm{c}}$, Ivana Perkovićc ${ }^{\mathrm{c}}$, Lidija Uzelac ${ }^{\mathrm{d}}$, Katja Ester ${ }^{\mathrm{d}}$, Marijeta Kralj

d, Marcel Kaiser ${ }^{\mathrm{e}}$, Matthias Rottmann ${ }^{\mathrm{e}}$, Fran Supek ${ }^{\mathrm{a},}{ }^{*}$, Branka Zorc ${ }^{\mathrm{c},}$ *

${ }^{a}$ Genome Data Science, Institute for Research in Biomedicine (IRB Barcelona), The Barcelona Institute of Science and Technology (BIST). Baldiri Reixac 10, 08028, Barcelona, Spain

b Department of Knowledge Technologies, Jožef Stefan Institute, Jamova cesta 39, SI-1000, Ljubljana, Slovenia ${ }^{c}$ Faculty of Pharmacy and Biochemistry, University of Zagreb, A. Kovačića 1, HR-10 000 Zagreb, Croatia

${ }^{d}$ Laboratory of Experimental Therapy, Division of Molecular Medicine, Rudjer Bošković Institute, Bijenička cesta 54, HR-10 000 Zagreb, Croatia

e Parasite Chemotherapy, Medical Parasitology \& Infection Biology, Swiss Tropical and Public Health Institute, 4051 Basel, Switzerland

* Corresponding authors.

E-mail addresses: fran.supek@irbbarcelona.org (F. Supek); bzorc@pharma.hr (B. Zorc). 
Primaquine (PQ) is a commonly used drug that can prevent the transmission of Plasmodium falciparum malaria, however its toxicity limits its use. We prepared five groups of PQ derivatives: amides 1a-k, ureas 2a-k, semicarbazides 3a,b, acylsemicarbazides $\mathbf{4 a - k}$ and bisureas 5a-v, and evaluated them for antimalarial activity in vitro against the erythrocytic stage of P. falciparum NF54. Particular substituents, such as trityl (in $\mathbf{2 j}$ and $\mathbf{5 r}$ ) and methoxybenzhydryl (in $\mathbf{3 b}$ and $\mathbf{5 v}$ ) were associated with a favorable cytotoxicity-to-activity ratio. To systematically link structural features of PQ derivatives to antiplasmodial activity, we performed a quantitativestructure activity relationship (QSAR) study using the Support Vector Machines machine learning method. This yielded a highly accurate statistical model $\left(R^{2}=0.776\right.$ in cross-validation), which was used to prioritize novel candidate compounds. Seven novel PQ-ureidoamides 10a-g were synthesized and evaluated for activity, highlighting the benzhydryl ureidoamides 10e and $10 f$ derived from $p$-chlorophenylglycine. Further experiments on human cell lines revealed that 10e and 10f are an order of magnitude less toxic than PQ in vitro while having antimalarial activity indistinguishable from PQ. The toxicity profile of novel compounds $\mathbf{1 0}$ toward human cells was particularly favorable when the glucose-6-phosphate dehydrogenase (G6PD) was inhibited, while toxicity of PQ was exacerbated by G6PD inhibition. Our work therefore highlights promising lead compounds for the development of effective antimalarial drugs that may also be safer for G6PD-deficient patients. In addition, we provide computational inference of antimalarial activity and cytotoxicity for thousands of PQ-like molecular structures.

Keywords: QSAR, Primaquine, Ureidoamide, Antimalarial activity, Plasmodium falciparum, Glucose-6-phosphate dehydrogenase 


\section{Introduction}

Malaria is an infectious disease affecting humans and animals, caused by parasitic protozoans belonging to the genus Plasmodium. Of the five species that cause malaria in humans, $P$. falciparum is responsible for most malaria-associated mortality worldwide and is the predominant species in tropical and subtropical countries. The World Health Organization tracks a decline in the global malaria burden due to more efficient drugs and better mosquito control. However, malaria is still a life-threatening disease: in 2015 alone, there were an estimated 212 million new cases of malaria and 429000 deaths [1].

Currently approved drugs include the artemisinins (artemisinin, dihydroartemisin, artemether, artesunate) and quinoline derivatives (chloroquine, amodiaquine, mefloquine, quinine and primaquine) [2]. Primaquine (PQ) is an 8-aminoquinoline antimalarial drug active against all species causing human malaria, including multi-resistant $P$. falciparum strains. PQ is the only clinically approved drug known to eliminate dormant liver forms of $P$. ovale and $P$. vivax [3]. In the case of $P$. falciparum malaria, PQ is uniquely effective in killing gametocytes produced during the sexual life stage of the parasite in the blood, disrupting the transmission of infection to mosquitoes and slowing the spread of the disease. This means that the biological activity profile of PQ (an 8-aminoquinoline) is different from standard 4-aminoquinoline antimalarial drugs such as chloroquine (CQ) or amodiaquine. In particular, CQ is active against the asexual blood stages (trophozoites) of $P$. falciparum, which feed on erythrocyte contents and therefore need to detoxify ingested heme, a process that CQ interferes with. In contrast, PQ is less effective against asexual blood stages of $P$. falciparum, but clears the sexual stage very efficiently. Therefore the 
underlying molecular mechanism of action of PQ likely differs from CQ and related drugs, and is not currently well understood.

Because of the unique biological activity profile, $\mathrm{PQ}$ is complementary to other antimalarials and is commonly added to drug regimens, with the primary goal of containing the spread of malaria (in P. falciparum) or preventing relapse (for species with dormant liver stages, $P$. ovale and $P$. vivax). However, toxicity of $\mathrm{PQ}$ is an important concern [4], particularly in patients with a deficiency in the glucose-6-phosphate dehydrogenase (G6PD) enzyme - a widespread genetic trait, particulary in disease-endemic regions. Globally 400 million people are estimated to be affected with G6PD deficiency [5]. The highest prevalence is found in tropical Africa and tropical/subtropical Asia: approx. 5-30\%, depending on the country and the method used to estimate the deficiency, reviewed in [6]. This constitutes a serious limitation to the broad use of PQ as an antimalarial agent. In practice, either the PQ dosage must be reduced in order to ameliorate side effects [7] or G6PD deficiency has to be tested in each patient before applying the drug [8], presenting a substantial logistical challenge in broad application of PQ. Toxicity to G6PD-deficient patients is a drawback specific to 8-aminoquinolines such as PQ and is not known to be pertinent for other quinoline drugs. In order to overcome this drawback and improve efficacy, various PQ derivatives have been synthesized and evaluated.

Recently published work bears witness that PQ derivatization and hybridization are interesting approaches in search of new antimalarials [9-22]. In particular, we have previously designed and prepared nearly a hundred primaquine derivatives of amide, urea, bis-urea, semicarbazide and acylsemicarbazide type, showing that they possess antiproliferative effects against human cell lines [23-29], however the antimalarial potential of these compounds has not been evaluated until now. Here we report the results of screening of selected PQ derivatives against $P$. 
falciparum and a detailed QSAR study which guided the synthesis of seven new compounds of general formula 10. They were active against malaria while exhibiting a very favorable toxicity profile towards human cells in vitro, which was retained even when the G6PD enzyme was inhibited.

\section{Results and discussion}

\subsection{Chemistry}

Six series of primaquine (PQ) derivatives were prepared and screened for antimalarial activity: amides 1, ureas 2, semicarbazides 3, acylsemicarbazides $\mathbf{4}$, bis-ureas 5 and ureidoamides $\mathbf{1 0}$. Their general structures are shown in Figure 1.
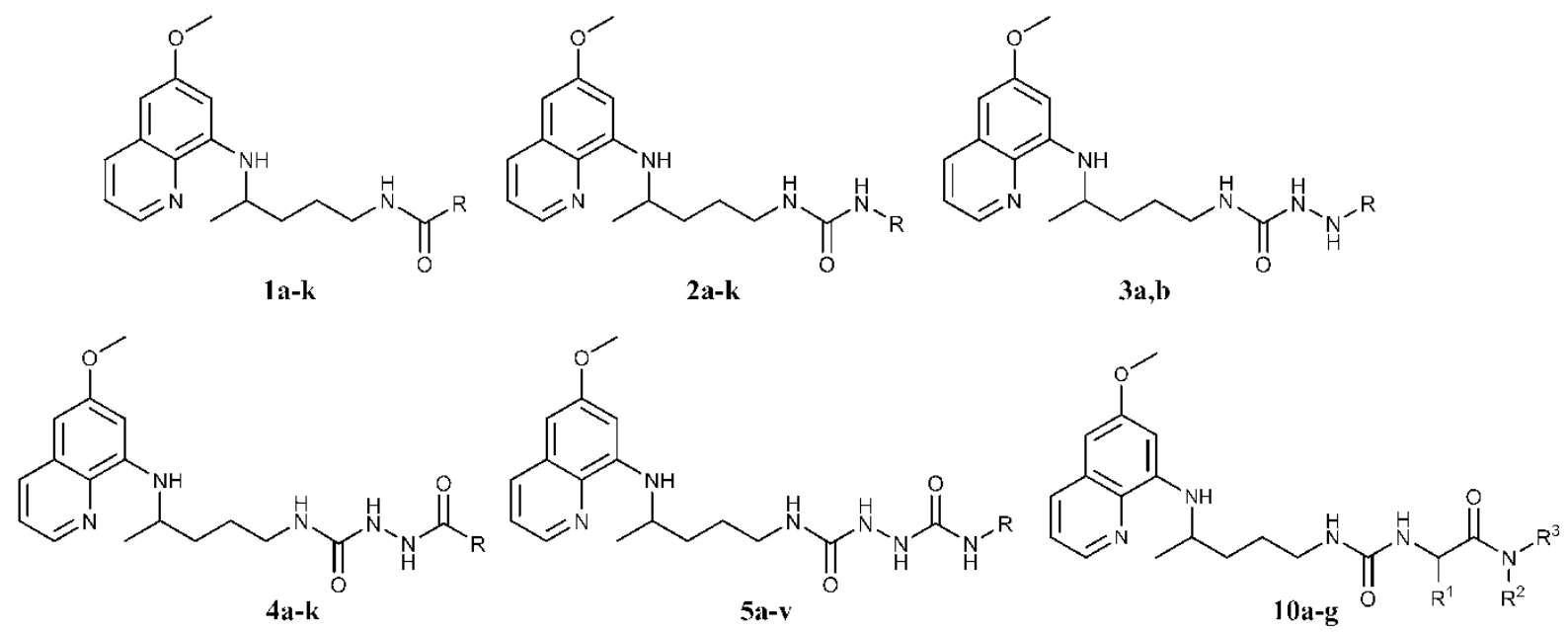

Fig. 1. Structures of the primaquine derivatives: amides 1a-k, ureas $\mathbf{2 a - k}$, semicarbazides 3a,b, acylsemicarbazides 4a-k, bis-ureas 5a-v and ureidoamides 10a-g.

Syntheses of derivatives $\mathbf{1 - 5}$ were previously published [23-29], while ureidoamides $\mathbf{1 0}$ are novel compounds, described here for the first time. The synthetic pathway leading to compounds 10 is outlined in Scheme 1. 


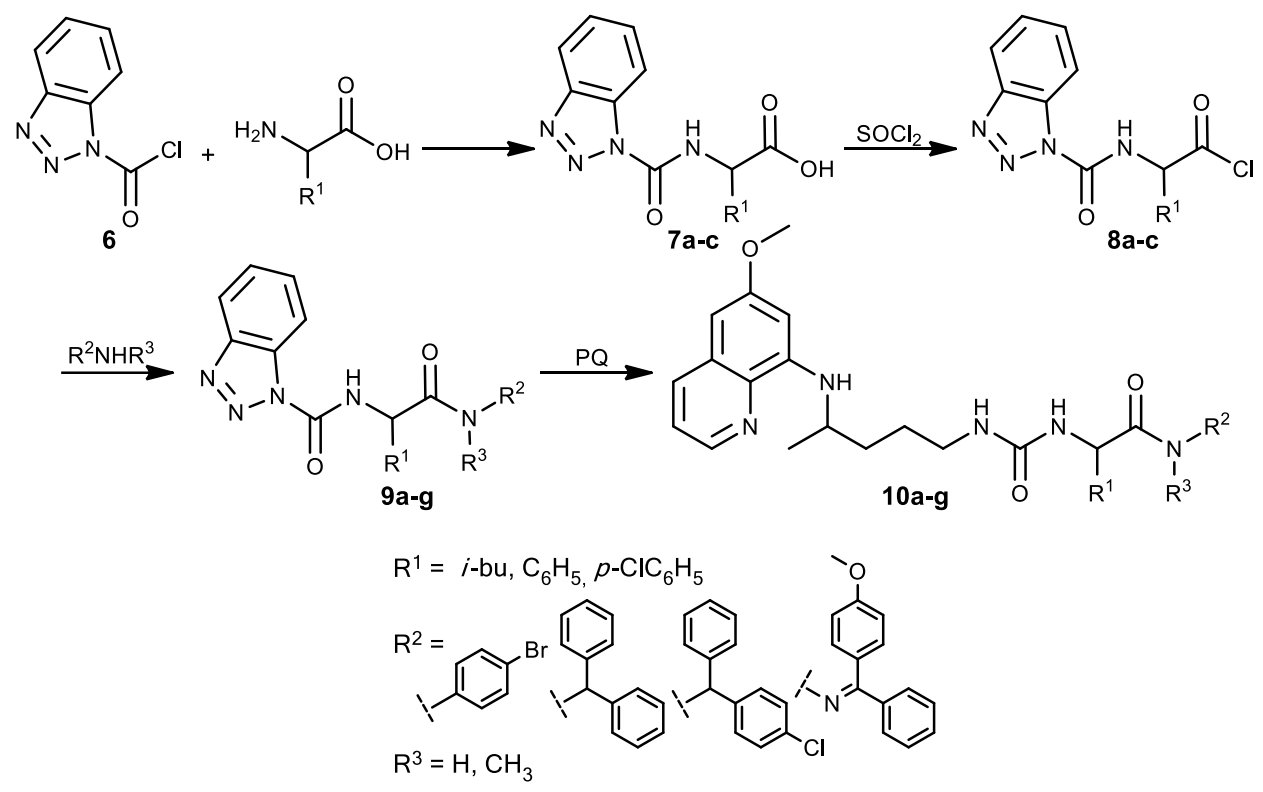

Scheme 1. Synthesis of ureidoamides 10.

Novel ureidoamides 10a-g with primaquine and amino acid moieties were prepared by aminolysis of $\mathrm{N}$-(1-benzotriazolecarbonyl)-amino acid amides 9a-g with primaquine, while amides 9 were obtained from $N$-(1-benzotriazolecarbonyl)-amino acid chlorides 8a-c and the corresponding amines or hydrazones. Three amino acids (L-leucine, D-phenylglycine, DL- $p$ chlorophenylglycine), four amines ( $p$-bromoaniline, diphenylmethanamine, (4chlorophenyl)(phenyl)methanamine)), $N$-methyl-1,1,diphenylmethanamine and one hydrazone (4-methoxybenzophenone hydrazone) were used. Synthesis of similar ureidoamides with various amines and amino acids was previously described by our group [30,31], as well as the synthesis of the starting $N$-(1-benzotriazolecarbonyl)-amino acids 7 and their chlorides 8 [32].

The presence of the primaquine residue in compounds $\mathbf{1 0 a - g}$ was confirmed by NMR spectra: hydrogen atoms close to pyridine nitrogen occurred in ${ }^{1} \mathrm{H}$ NMR spectra between 8.54 and 8.52, aromatic hydrogen in $p$-position from pyridine nitrogen atom at $8.09-8.06$, hydrogen bound to nitrogen close to quinoline ring from 6.13 to 5.97 , methoxy group at 3.82-3.81, $\mathrm{CH}$ of PQ chiral 
carbon as a multiplet at 3.62-3.57, and finally methyl group between 1.21 and $1.19 \mathrm{ppm}$. All NH signals were $\mathrm{D}_{2} \mathrm{O}$ exchangeable.

The presence of carbonyl groups in $N$-(1-benzotriazolecarbonyl)-amino acid amides 9a-g was indicated by the appearance of two strong stretching vibration bands in IR spectra, the first between 1750 and $1716 \mathrm{~cm}^{-1}$ and the second between 1682 and $1649 \mathrm{~cm}^{-1}$, while two carbonyl groups in products 10 were located at lower wavenumbers (between 1650 and $1509 \mathrm{~cm}^{-1}$ ).

In ${ }^{13} \mathrm{C}$ NMR spectra carbonyl groups close to benzotriazole in products 9 appeared between 148.84 and $147.40 \mathrm{ppm}$ and amide carbonyls between 172.20 and $167.39 \mathrm{ppm}$. Urea carbonyl groups in products $\mathbf{1 0}$ were shifted to lower ppm values (from 157.62 to 153.85), while amide carbonyl appeared between 172.46 and $169.45 \mathrm{ppm} . \mathrm{C}=\mathrm{N}$ group in product $10 \mathrm{~g}$ appeared at $155.00 \mathrm{ppm}$. Phenyl moieties gave expected signals in aromatic region and appropriate carbon count. Structures of compounds 9 f and $9 \mathrm{~g}$ were confirmed indirectly, after chemical derivatization to products $10 \mathrm{f}$ and $\mathbf{1 0 g}$, respectively.

Mass spectroscopy gave molecular ion peaks which corresponded to expected molecular formulas for all prepared compounds from series $\mathbf{1 0}$. In series $\mathbf{9}$, molecular ion peaks were visible only in spectra of $9 \mathbf{e}$ and $9 \mathrm{~g}$. Other compounds of general formula 9 gave only benzotriazole fragment at $\mathrm{m} / \mathrm{z} 120.1$ or 117.9. Chemical structures of compounds 10a-g were also supported by CHN analyses.

\subsection{Antimalarial screening}

The compound series 1-5 were evaluated for their antimalarial activity against the erythrocytic stage of the Plasmodium falciparum NF54 strain, while an initial estimate of their cytotoxicity towards mammalian cells was obtained using the L6 cell line derived from rat skeletal 
myoblasts. The $\mathrm{IC}_{50}$ values (the concentration of the tested compound necessary for $50 \%$ growth inhibition) and cytotoxicity data are given in Table 1. As a simple measure of a compound's potential utility, we use a selectivity index (SI), here defined as ratio of the cytotoxicity (towards L6 cells) and the antimalarial activity $\mathrm{IC}_{50}$ values. For reference, the SI of primaquine in our experimental system (see Materials and Methods) was 39.6.

While the majority of tested compounds exhibited a certain level of antimalarial activity, some series appeared more promising than others. For instance, all PQ-cinnamic acid derivatives of the amide type (1a-k) showed modest antimalarial activity, with $\mathrm{IC}_{50}$ roughly an order of magnitude higher than PQ, ranging between 8 and $25 \mu \mathrm{M}$; we note a somewhat more favorable profile in the trimethoxy derivative 1e. Similarly, the PQ-cinnamic acid acylsemicarbazides 4a-k showed modest activity overall, with one potential exception being the trimethoxy derivative $4 \mathbf{e}$ with SI $=30$ (antimalarial $\mathrm{IC}_{50} 4.5 \mu \mathrm{M}$ and cytotoxicity $138.2 \mu \mathrm{M}$ ), thereby approximately matching the parent compound (PQ). Therefore, series $\mathbf{1}$ and $\mathbf{4}$ do not overall appear promising, with certain exceptions.

In contrast, other PQ derivative series had multiple members with favorable activity and cytotoxicity, which were dependant on the substituents. In particular, the urea series $\mathbf{2 a - 2 k}$ contained lowly active hydroxyalkyl and cycloalkyl derivatives, however the chlorobenzhydryl urea $\mathbf{2} \mathbf{i}$, a compound with two PQ moieties $2 \mathbf{k}$ and especially the trityl urea $\mathbf{2} \mathbf{j}$ were active and moreover had a high SI (33, 28 and 113, respectively). Concerning the large series of bis-urea derivatives 5a-v, hydroxyalkyl and cycloalkyl derivatives were again lowly active. Halogenated aryl and biaryl derivatives had modest activity ( $\mathrm{IC}_{50}$ from 7.5 to $\left.17.8 \mu \mathrm{M}\right)$ and exhibited some cytotoxicity. The most interesting compound was again the trityl derivative $\mathbf{5 r}$, which exhibited SI $>80\left(\mathrm{IC}_{50} 1.2 \mu \mathrm{M}\right.$ and cytotoxicity $\left.>100 \mu \mathrm{M}\right)$. Furthermore, compound $\mathbf{5 v}$ bearing a 
dimethoxybenzhydryl substituent was highly active (at PQ-like levels, $2.2 \mu \mathrm{M}$ ). The two semicarbazides in series $\mathbf{3}$ (3a and $\mathbf{3 b}$ ), which also bear methoxybenzhydryl groups, showed high activity and low cytotoxicity as well.

In summary, the trityl compounds $\mathbf{2} \mathbf{j}$ and $\mathbf{5} \mathbf{r}$ represent active PQ derivatives with apparently improved selectivity over the parent compound, PQ (SI 113 and 80, respectively, compared to SI of primaquine 39.6), as estimated in our experimental system. The dimethoxybenzhydryl compounds $\mathbf{3 b}$ and $\mathbf{5 v}$ also appear highly promising, with SI 78.3 and 61.8, respectively. Motivated by these examples where favorable biological properties appear linked to certain substituents, we further developed a QSAR model to direct the synthesis of a novel series of antimalarial lead compounds based on PQ.

\section{Table 1}

In vitro screening of primaquine derivatives against erythrocytic stage of $P$. falciparum and cytotoxicity towards L6 rat cells.

\begin{tabular}{|c|c|c|c|c|c|c|}
\hline Compd. & Structural formula & $\begin{array}{c}\text { Antimalarial } \\
\text { activity }^{\mathrm{a}} \\
\mathrm{IC}_{50}, \mu \mathrm{M}\end{array}$ & $\begin{array}{l}\text { Cytotox- } \\
\text { icity }^{\mathrm{a}} \\
\mathrm{IC}_{50}, \mu \mathrm{M}\end{array}$ & $\mathrm{SI}^{\mathrm{b}}$ & $\begin{array}{l}\text { Synth. } \\
\text { Ref. }^{c}\end{array}$ & $\begin{array}{c}\text { QSAR } \\
\text { train/test set }\end{array}$ \\
\hline $1 \mathrm{a}$ & & 15.1 & 18.5 & 1.2 & [29] & Test \\
\hline $1 \mathrm{~b}$ & & $>24.8$ & $>250$ & 10.1 & [29] & Test \\
\hline 1c & & 12.4 & $>240$ & 19.4 & [29] & Test \\
\hline 1d & & 11.9 & $>220$ & 18.5 & [29] & Test \\
\hline
\end{tabular}




\begin{tabular}{|c|c|c|c|c|c|}
\hline $1 \mathrm{e}$ & 8.1 & $>210$ & 25.9 & [29] & Test \\
\hline 1f & 22.1 & 29 & 1.3 & [29] & Test \\
\hline $1 g$ & 13.7 & 16.8 & 1.2 & [29] & Test \\
\hline $1 \mathrm{~h}$ & 13.2 & 3.5 & 0.3 & [29] & Test \\
\hline $1 \mathbf{i}$ & 15.6 & 16.2 & 1.0 & [29] & Test \\
\hline $1 \mathrm{j}$ & 12.9 & 160 & 12.4 & [29] & Test \\
\hline $1 k$ & 11.3 & 158.1 & 14.0 & [29] & Test \\
\hline $2 a$ & 27.4 & n.d. ${ }^{\mathrm{d}}$ & n.d. & [24] & Train \\
\hline $2 b$ & 52.4 & n.d. & n.d. & [24] & Train \\
\hline $2 c$ & 65.9 & n.d. & n.d. & [23] & Train \\
\hline $2 d$ & 42.1 & n.d. & n.d. & [23] & Train \\
\hline $2 e$ & 8.1 & n.d. & n.d. & [23] & Train \\
\hline $2 f$ & 47.3 & n.d. & n.d. & [23] & Train \\
\hline $2 g$ & 17.1 & n.d. & n.d. & [26] & Train \\
\hline
\end{tabular}




\begin{tabular}{|c|c|c|c|c|c|}
\hline $2 h$ & 11.9 & 14.9 & 1.3 & [28] & Test \\
\hline $2 \mathrm{i}$ & 4.3 & 140 & 32.6 & {$[26,27]$} & - \\
\hline $2 j$ & 1.5 & $>171$ & 114.0 & [26] & Train \\
\hline $2 \mathrm{k}$ & 6.4 & $>180$ & 28.1 & [26] & Train \\
\hline $3 \mathbf{a}$ & 4.1 & $>195$ & 47.6 & [26] & Train \\
\hline $3 \mathbf{b}$ & 2.3 & $>180$ & 78.3 & [26] & Train \\
\hline $4 a$ & 17.2 & 13.9 & 0.8 & [29] & Test \\
\hline $4 b$ & 22.9 & 36.5 & 1.6 & [29] & Test \\
\hline $4 c$ & 22.2 & 3.6 & 0.2 & [29] & Test \\
\hline $4 d$ & $>19.7$ & 37 & 1.9 & [29] & Test \\
\hline $4 e$ & 4.5 & 138.2 & 30.7 & [29] & Test \\
\hline $4 f$ & 20.4 & 15.5 & 0.8 & [29] & Test \\
\hline $4 g$ & 24.2 & 7.3 & 0.3 & [29] & Test \\
\hline $4 h$ & $>21.4$ & 25.1 & 1.2 & [29] & Test \\
\hline
\end{tabular}




\begin{tabular}{|c|c|c|c|c|c|}
\hline $4 i$ & $>19.4$ & 10.6 & 0.5 & [29] & Test \\
\hline $4 \mathbf{j}$ & $>19.4$ & 28.3 & 1.5 & [29] & Test \\
\hline $4 k$ & $>17.1$ & $>170$ & 9.9 & [29] & Test \\
\hline $5 \mathbf{a}$ & 58.8 & n.d. & n.d. & [26] & Train \\
\hline $5 b$ & 43.7 & n.d. & n.d. & [26] & Train \\
\hline $5 c$ & 41.4 & 178.1 & 4.3 & {$[26,27]$} & - \\
\hline $5 d$ & 66.7 & n.d. & n.d. & [26] & Train \\
\hline $5 e$ & 75.4 & n.d. & n.d. & [25] & Train \\
\hline $5 f$ & 46.3 & n.d. & n.d. & [25] & Train \\
\hline $5 g$ & $>111.0$ & n.d. & n.d. & [25] & Train \\
\hline $5 \mathrm{~h}$ & 27.1 & n.d. & n.d. & [25] & Train \\
\hline $5 \mathbf{i}$ & 14.9 & 58.6 & 3.9 & [28] & Test \\
\hline $5 \mathbf{j}$ & 17.8 & 91.9 & 5.2 & [28] & Test \\
\hline $5 k$ & 17.8 & 38.7 & 2.2 & [28] & Test \\
\hline 51 & 11.8 & 32.1 & 2.7 & [28] & Test \\
\hline
\end{tabular}




\begin{tabular}{|c|c|c|c|c|c|}
\hline $5 \mathrm{~m}$ & 10.3 & 14.9 & 1.4 & [28] & Test \\
\hline $5 n$ & 15.2 & n.d. & n.d. & [26] & Train \\
\hline 50 & 10.3 & n.d. & n.d. & [25] & Train \\
\hline $5 p$ & 10.0 & 10.4 & 1.0 & [26] & Test \\
\hline $5 q$ & 7.5 & 8.4 & 1.1 & {$[26,27]$} & - \\
\hline $5 r$ & 1.2 & $>100$ & 83.3 & [26] & Test \\
\hline $5 s$ & 3.7 & 76.6 & 20.7 & {$[26,27]$} & - \\
\hline $5 t$ & 20.8 & n.d. & n.d. & [25] & Train \\
\hline $5 \mathbf{u}$ & 5.6 & 16.0 & 2.9 & [26] & Train \\
\hline $5 v$ & 2.2 & 136.1 & 61.9 & [26] & Train \\
\hline $10 a$ & 3.4 & $>170$ & 50.0 & this work & Test \\
\hline 10b & 6.5 & $>140$ & 21.5 & this work & Test \\
\hline $10 \mathrm{c}$ & 3.0 & $>160$ & 53.3 & this work & Test \\
\hline 10d & 3.2 & 54.0 & 16.9 & this work & Test \\
\hline
\end{tabular}




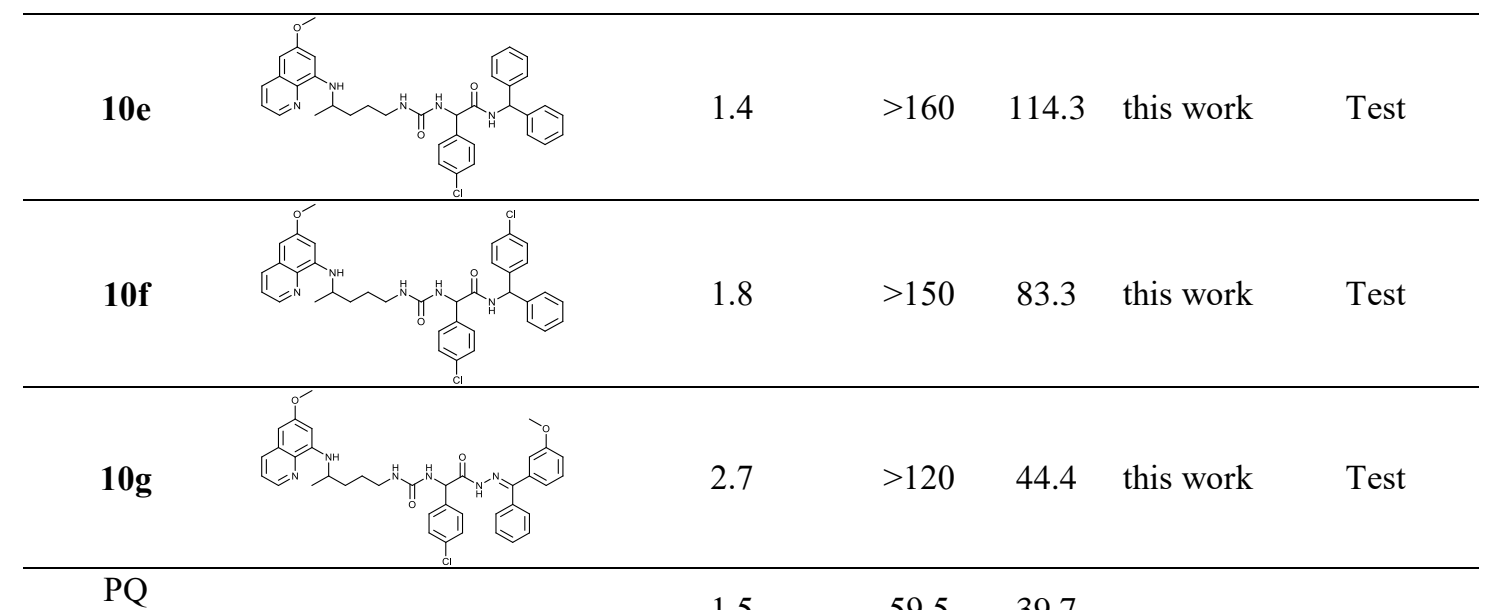

diphosphate

$\begin{array}{lll}1.5 & 59.5 & 39.7\end{array}$

${ }^{a} \mathrm{IC}_{50}$ - the concentration of the compound necessary for $50 \%$ growth inhibition of $P$. falciparum or L6 rat myoblast cells; the displayed numbers are averages of two or three independent experiments. ${ }^{\mathrm{b}} \mathrm{SI}$ - selectivity index, defined as a ratio of the cytotoxicity and the antimalarial activity. ${ }^{\mathrm{c}}$ Reference for synthesis. ${ }^{\mathrm{d}}$ n.d. - not determined.

\subsection{Quantitative structure-activity relationship modeling}

The QSAR model for prediction of antimalarial activity ( $\log \mathrm{IC}_{50}$ against the P. falciparum NF54 strain) was trained using the Support Vector Machines (SVM) algorithm. SVMs are a machine learning method known to have a high predictive accuracy and to generalize well to novel data sets and are therefore increasingly used also for QSAR studies [33], including our previous work for modeling biological activity of peptides, ionophores, and substrate specificity of a human protein [34-36]. Here, the SVM regression model was trained on a set of 56 compounds (structures provided in Supporting Information), which consisted of 23 PQ derivatives from this study (series 1-5; Table 1) and additional 33 compounds from published data by Kaur et al. [3739] that were sufficiently similar in structure to the original 23 compounds; see Materials and Methods for how the QSAR applicability domain was defined. The SVM model had a high accuracy in predicting activity against $P$. falciparum when tested in cross-validation: $R^{2}=0.776$; root-mean-square error $(\mathrm{RMSE})=0.294$ when predicting $\log _{10} \mathrm{IC}_{50}$ units (Figure $\left.2 \mathrm{a}\right)$. In other 
words, we estimate that our SVM model can predict the $\mathrm{IC}_{50}$ of a PQ derivative within a 1.97fold range of the actual value $\left(10^{0.294}\right)$. Moreover, the model retained much of the predictive accuracy when tested on an independent test set of 37 PQ derivatives that are within the model's applicability domain (see Materials and Methods), yielding a RMSE $=0.403 \log _{10}$ units of $\mathrm{IC}_{50}$ (Figure 2b), implying a good qualitative agreement of the model to observed data. If the compounds are classed into two groups, lowly active (above-median $\mathrm{IC}_{50} \geq 8.9 \mu \mathrm{M}$ ) and highly active (below-median $\mathrm{IC}_{50}<8.9 \mu \mathrm{M}$ ) compounds, our predictions would be $91 \%$ accurate on the training set, and 95\% accurate on the independent test set (measuring the fraction compounds assigned to the correct class; Figure 2d). Therefore, this appears to be a useful statistical model to prioritize the synthesis of further PQ derivatives with antiplasmodial activity.
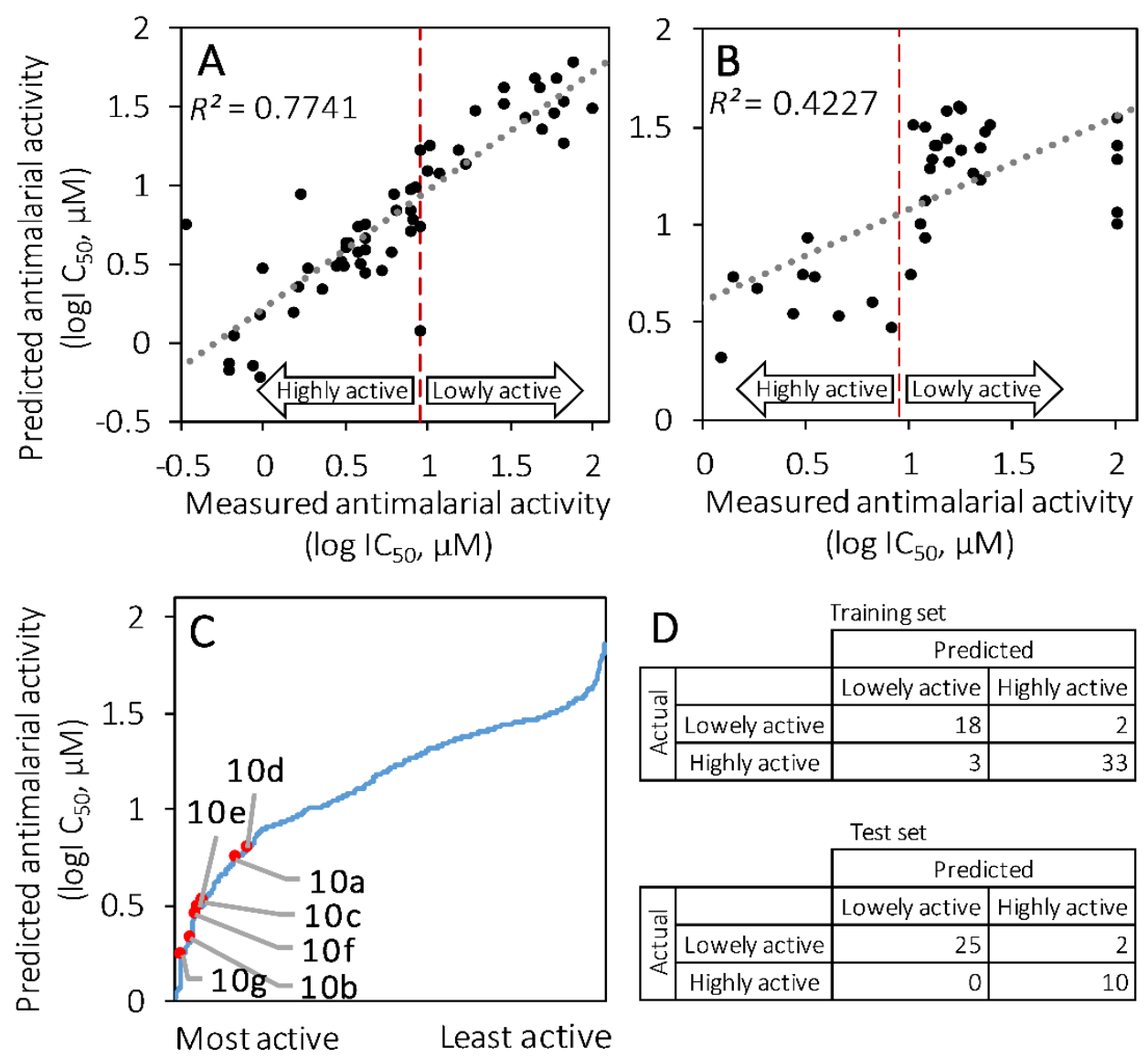
Fig. 2. Measured and predicted activity of 56 training set compounds (A) and 37 testing compounds (B); Predicted activities of an in house library of 522 compounds, sorted from the most active to the least active compound (C); Qualitative agreements of the model's predictions with the observed data (D). Novel ureidoamides 10a-g are marked with red dots. Predicted activities for the training compounds were obtained in ten-fold cross-validation.

Next, the SVM model was applied to infer the antimalarial activity of an in-house virtual library of 522 molecules; the structures and activity predictions are supplied in Supporting Information. Based on their high predicted antimalarial activity (Figure $2 \mathrm{c}$ ) and further considerations related to chemical synthesis, seven PQ ureidoamides $\mathbf{1 0 a - g}$ bearing an amino acid residue were selected for synthesis and evaluation against $P$. falciparum and for an initial cytotoxicity screen using the L6 mammalian cell line.

\subsection{Antimalarial activity and cytotoxicity of novel $P Q$ ureidoamides}

Indeed, four out of seven compounds from the series $\mathbf{1 0}$ showed a favorable cytotoxicity/antimalarial activity ratio, with $\mathrm{SI}>50(\mathrm{PQ}$ has $\mathrm{SI}=39.6)$. The benzhydryl ureidoamide derived from $p$-chlorophenylglycine 10e was the most promising of all 64 tested compounds, with SI $>114$, followed by chlorobenzhydryl derivative 10f with $\mathrm{SI}>83$. While the compounds 10e and 10f have very similar antiplasmodial activity as the parent compound, PQ (Table 1), they are at least 2.7 and 2.5-fold less cytotoxic relative to PQ in this particular in vitro model using L6 rat skeletal myoblasts. Of note, these are conservative estimates, given that the L6 experimental assay reached the boundary of its detection range; in other words, the actual toxicity of $\mathbf{1 0 e}$ and $\mathbf{1 0 f}$ may be even lower. 
To follow up on the initial observation of reduced cytotoxicity in rat L6 cells, we performed growth inhibition screens on four human tumor cell lines from diverse tissues: H460 (lung), MCF-7 (breast), SW620 (colon) and A2780 (ovary); Table 2. For the novel compounds in series 10, human cell lines suggest at least an order of magnitude reduced cytotoxicity compared to PQ (Tables 2 and S1). Compound 10e in particular did not reach $\mathrm{IC}_{50}$ up to the maximum tested concentration of $100 \mu \mathrm{M}$ in three of the four cell lines, and similarly so for $10 \mathrm{f}$. Therefore, 10e and $\mathbf{1 0 f}$ are at least 13 -fold less toxic than PQ, which has median $\mathrm{IC}_{50}$ across cell lines $7.5 \mu \mathrm{M}$ (range 5 to $14 \mu \mathrm{M}$ ) in this model system (Table 2). Compound 10c also exhibits a favorable toxicity profile (non-toxic up to $100 \mu \mathrm{M}$ in all four human cell lines; Table 2) and retains much of the activity $\left(P\right.$. falciparum $\left.\mathrm{IC}_{50}=3.0 \mu \mathrm{M}\right)$. In this respect, the novel compounds $\mathbf{1 0}$ appear to be a large improvement over other PQ derivative series tested here: while the above-reported compounds $\mathbf{3 b}, \mathbf{5 r}$ and $\mathbf{5 v}$ exhibited PQ-like antimalarial activity (Table 1), they are also similarly cytotoxic to human cells as PQ (Table 2), in stark contrast to 10c, 10e and 10f which are substantially less cytotoxic than PQ. Of note, our data for $10 \mathrm{c}, 10 \mathrm{e}$ and $\mathbf{1 0 f}$ were measured across five independent experiments (biological replicates) for the H460 and MCF-7 cell lines and at least two experiments in SW620 and A2780 cells (Table 2), suggesting robust results. To further examine effects on a broader panel of human tissues, we also tested against the tumorderived cell lines HCT 116 (colon), HL-60 and K562 (blood/myeloid lineage) and Capan-1 (pancreatic). All compounds from series $\mathbf{1 0}$ had very low cytotoxicity also on all these additional cell lines ( $\mathrm{IC}_{50}>100 \mu \mathrm{M}$; single biological replicate), unlike PQ (Table S1).

\section{Table 2}

$\mathrm{IC}_{50}$ values $^{\mathrm{a}}$ (in $\mu \mathrm{M}$; mean \pm standard deviation) for human cell lines 
Cell lines

\begin{tabular}{|c|c|c|c|c|}
\hline & H460 & MCF-7 & SW620 & A2780 \\
\hline $3 b$ & $\begin{array}{l}>100 \\
(n=3)^{\mathbf{b}}\end{array}$ & $\begin{array}{l}3 \pm 0.4 \\
(n=2)\end{array}$ & $\begin{array}{l}>100^{c} \\
(n=2)\end{array}$ & $\begin{array}{l}1 \pm 0.1 \\
(n=3)\end{array}$ \\
\hline $5 r$ & $\begin{array}{l}3 \pm 0.3 \\
(n=2)\end{array}$ & $\begin{array}{c}3 \pm 2 \\
(n=2)\end{array}$ & $\begin{array}{l}7 \pm 4^{c} \\
(n=2)\end{array}$ & $\begin{array}{l}1 \pm 0.2 \\
(n=2)\end{array}$ \\
\hline $5 v$ & $\begin{array}{l}5 \pm 0.3 \\
(n=2)\end{array}$ & $\begin{array}{l}1 \pm 0.5 \\
(n=2)\end{array}$ & $\begin{array}{l}>100^{c} \\
(n=2)\end{array}$ & $\begin{array}{c}0.06 \pm 0.01 \\
(n=3)\end{array}$ \\
\hline $10 \mathrm{a}$ & $\begin{array}{l}>100 \\
(\mathrm{n}=5)\end{array}$ & $\begin{array}{l}>100 \\
(n=4)\end{array}$ & $\begin{array}{c}>100 \\
(n=3)\end{array}$ & $\begin{array}{l}36 \pm 29 \\
(n=3)\end{array}$ \\
\hline $10 \mathrm{~b}$ & $\begin{array}{c}64 \pm 32 \\
(n=2)\end{array}$ & $\begin{array}{l}>100 \\
(n=2)\end{array}$ & $\begin{array}{l}>100 \\
(n=3)\end{array}$ & n. t. ${ }^{\mathrm{d}}$ \\
\hline $10 \mathrm{c}$ & $\begin{array}{l}>100 \\
(n=5)\end{array}$ & $\begin{array}{l}>100 \\
(n=5)\end{array}$ & $\begin{array}{l}>100 \\
(n=3)\end{array}$ & $\begin{array}{l}>100 \\
(n=2)\end{array}$ \\
\hline 10d & $\begin{array}{l}52 \pm 31 \\
(n=2)\end{array}$ & $\begin{array}{c}16 \pm 0.2 \\
(n=2)\end{array}$ & $\begin{array}{l}32 \pm 8 \\
(n=3)\end{array}$ & n. t. \\
\hline $10 \mathrm{e}$ & $\begin{array}{l}>100 \\
(n=5)\end{array}$ & $\begin{array}{l}>100 \\
(n=5)\end{array}$ & $\begin{array}{c}6 \pm 1 \\
(n=3)\end{array}$ & $\begin{array}{l}>100 \\
(n=2)\end{array}$ \\
\hline $10 f$ & $\begin{array}{l}>100 \\
(n=5)\end{array}$ & $\begin{array}{l}>100 \\
(n=5)\end{array}$ & $\begin{array}{l}>100 \\
(n=3)\end{array}$ & $\begin{array}{l}14 \pm 4 \\
(n=2)\end{array}$ \\
\hline $10 \mathrm{~g}$ & $\begin{array}{l}>100 \\
(n=2)\end{array}$ & $\begin{array}{l}>100 \\
(n=2)\end{array}$ & $\begin{array}{l}>100 \\
(n=3)\end{array}$ & n. t. \\
\hline PQ & $\begin{array}{l}10 \pm 5 \\
(n=3) \\
\end{array}$ & $\begin{array}{c}5 \pm 2 \\
(n=6) \\
\end{array}$ & $\begin{array}{l}14 \pm 2 \\
(n=3)\end{array}$ & $\begin{array}{l}5 \pm 0.2 \\
(n=2)\end{array}$ \\
\hline
\end{tabular}

${ }^{\mathrm{a}} \mathrm{IC}_{50}$ - the concentration that causes $50 \%$ growth inhibition. ${ }^{\mathrm{b}}$ Number of independent experiments (biological replicates) given in parentheses. ${ }^{c}$ Values previously reported by Pavić et al. [23]. ${ }^{d}$ n. t. - not tested.

\subsection{Cytotoxicity in G6PD-deficient cells}

One important mechanism of PQ toxicity in patients is related to the G6PD enzyme, wherein the persons with an inherited deficiency of G6PD may suffer severe side effects, in particular hemolytic anemia $[40,41]$. We therefore asked whether the favorable cytotoxicity profile of novel compounds $\mathbf{1 0}$ is retained or abolished in G6PD-deficient cells, in comparison to PQ and the most promising previous PQ derivatives from series $\mathbf{3}$ and $\mathbf{5}$. To investigate, we applied a 
G6PD inhibitor 6-aminonicotinamide (6-AN) to the human cell lines H460 and MCF-7, thereby reducing G6PD activity in the cells. We observed that in highly active PQ derivatives $\mathbf{3 b}, \mathbf{5} \mathbf{r}$ and $\mathbf{5 v}$, the cytotoxicity is aggravated upon G6PD inhibition (Figures $3 \mathbf{c}$ and $3 \mathrm{~d}$ ), similarly as for PQ itself (Figures $3 a$ and $3 b$ ).

In particular, applying $10 \mu \mathrm{M}$ of PQ by itself lowers the MCF-7 cell growth rate to $25 \%$ of the untreated cells (meaning, growth is reduced by three-quarters, but there is still a net increase in number of cells; Figures $3 a$ and $3 b$ ). However, the same PQ concentration in combination with 6-AN (at $10 \mu \mathrm{M}$ ) results in a negative growth rate of approx. $-45 \%$, meaning there is much cell death occurring caused by PQ in the G6PD-inhibited cells. In other words, there is a synergistic effect on cytotoxicity by PQ and G6PD inhibition (Figures 3a and 3b). In contrast, a highly cytotoxic cancer drug not known to act in a G6PD-dependent manner, paclitaxel, does not show synergies with 6-AN (Figures $3 \mathrm{a}$ and $3 \mathrm{~b}$ ). The toxicity of 6-AN itself - always applied at $10 \mu \mathrm{M}$ - for the H460 and MCF-7 cell lines is modest and thus unlikely to confound results $(82 \%$ growth rate for MCF-7 and 87\% for $\mathrm{H} 460$ for 6-AN only).

We next turned to examine the effects of G6PD inhibition on the cytotoxicity of the novel compounds 10a, 10c, 10e and 10f in human cell lines (Figures $3 \mathrm{e}$ and $3 \mathrm{f}$ ). There was little difference in growth inhibition of the $\mathrm{H} 460$ and MCF-7 cells regardless of if the G6PD inhibitor was simultaneously applied or not. In particular, at $10 \mu \mathrm{M}$, compound $10 \mathrm{e}$ results in $>50 \% \mathrm{MCF}-$ 7 cell growth with or without 6 -AN ( $80 \%$ vs. $65 \%$ ) and equally so with the compound $\mathbf{1 0 f}(93 \%$ vs. $76 \%$ ). The observable difference is in line with the effect size due to applying 6-AN itself (approx. 15\%) and therefore there does not appear to be a synergistic effect of 10e and 10f with G6PD inhibition, unlike PQ ( $25 \%$ vs. $-45 \%$, which amounts to a $70 \%$ difference) and unlike the previous compounds $3 \mathbf{b}, \mathbf{5 r}$ and $\mathbf{5 v}$ (Figure $3 \mathrm{c}$ and $3 \mathrm{~d}$ ). The compounds 10a and 10c show a 
similar pattern, indicating that G6PD inhibition does not substantially aggravate their toxicity (Figures 3e and 3f). H460 cells broadly uphold these results for 10a, 10c and 10f. Overall, our data suggest that the novel PQ derivatives synthetized herein are promising lead compounds for antimalarial drugs with an improved safety profile for G6PD-deficient patients. Testing of compounds $\mathbf{1 0}$ and their derivatives in other cell types and in model animals is therefore warranted to further establish the medicinal potential of these novel PQ derivatives.
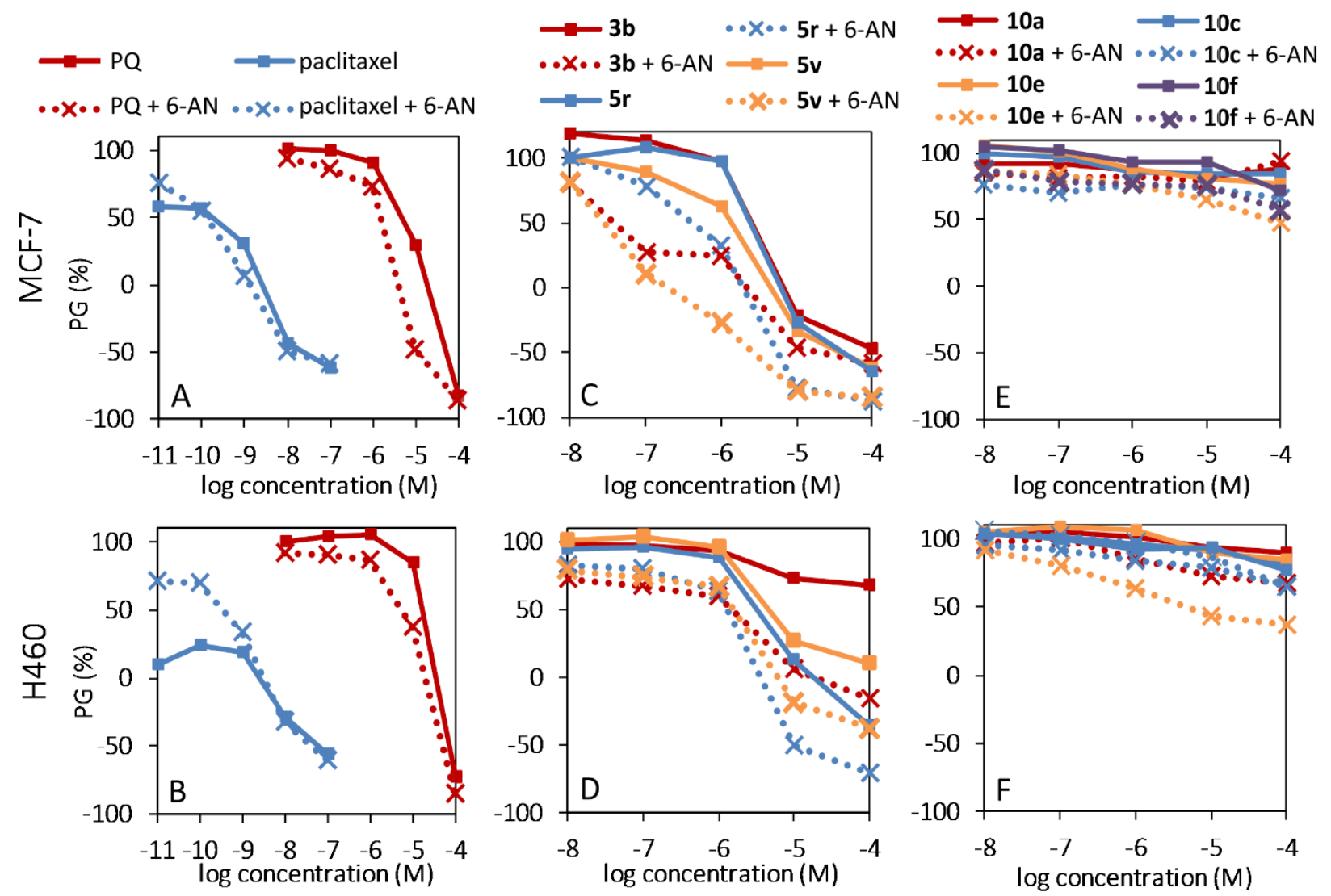

Fig. 3. The effects of G6PD inhibition on the cytotoxicity of the compounds to MCF-7 and H460 cell lines; controls (A and B), PQ-derivatives (C and D) and newly synthetized ureidoamides (E and F).

\subsection{A comprehensive resource of predicted antimalarial activity and cytotoxicity of $P Q$-like} compounds 
Our efforts to computationally model the structure-activity relationship of PQ derivatives resulted in a highly accurate predictor based on the SVM algoritm. We were thus further motivated to employ computational modeling to provide a library of predictions for a broad set of 13,401 PQ-like molecular structures extracted from PubChem; see Supporting Text S1 for a description of the modeling, and see Supporting Information for the inferred biological activities. In brief, we predicted 199 compounds to be simultaneously more active and less cytotoxic than PQ itself (predictions listed in Supporting Information). While we took precautions to ensure that the molecular structures of the $>13,000$ tested compounds are reasonably consistent with the training set of PQ derivatives (see section 4.3.3), we advise caution in interpreting the predictions, given that QSAR models tend to become less reliable as structures diverge. We recovered individual examples of correct predictions in this data set, as suggested by a literature search (see Supporting Text S1 and Figure S1). If further validated by independent data, this database of predicted activities could serve as a useful resource to inspire future research on antimalarial PQ derivatives.

\section{Conclusions}

PQ and its derivatives are important drugs for treatment of various types of malaria, where in particular PQ has a unique ability to prevent $P$. falciparum transmission by killing the gametocytes of the parasite in the bloodstream. However, applying PQ at a broad scale is complicated by severe toxicity towards a subset of patients with an inherited G6PD deficiency. Therefore, there is a need for novel derivatives of PQ which would retain or improve its efficacy, while presenting a more favorable toxicity profile. Here, we evaluated the activity of 64 diverse PQ derivatives against the erythrocytic stage of the P. falciparum NF54 strain. PQ-cinnamic acid amides $\mathbf{1 d}$ and $\mathbf{1 e}$, chlorobenzhydryl $\mathbf{2} \mathbf{i}$, trityl $\mathbf{2 \mathbf { j }}$ and $\mathbf{2} \mathbf{k}$ urea with two PQ residues, PQ-cinnamic 
acid semicarbazide $4 \mathbf{e}$, the trityl bis-urea $\mathbf{5 r}$ and the methoxybenzhydryl compounds $3 \mathbf{b}$ and $\mathbf{5 v}$ showed high activities. Based on these experimental measurements, a QSAR model prioritized a novel series of PQ ureidoamides 10a-g that we designed, prepared and evaluated against $P$. falciparum and mammalian cells. The results confirmed high activity and low cytotoxicity of ureidoamides 10, especially of benzhydryl and chlorobenzhydryl compounds 10e and 10f derived from $p$-chlorophenylglycine. These showed antimalarial activity comparable with PQ, but at least an order of magnitude lower cytotoxicity to various human cell types and in particular their toxic effects were not notably aggravated in G6PD-inhibited cells, in contrast to PQ. We suggest that 10a-g constitute promising lead compounds for development of more effective and safer drugs for malaria treatment, particularly for G6PD-deficient patients. Furthermore, our computational models predict hundreds of additional PQ-related compounds with favorable antimalarial activity and cytotoxicity profiles, highlighting new avenues for future research efforts.

\section{Materials and methods}

\subsection{Synthesis}

\subsubsection{General information}

Melting points were measured on a Stuart Melting Point (SMP3) apparatus (Barloworld Scientific, UK) in open capillaries with uncorrected values. IR spectra were recorded on FTIR Perkin Elmer Spectrum One and UV-Vis spectra on Lambda 20 double beam spectrophotometer (Perkin-Elmer, UK). All NMR $\left({ }^{1} \mathrm{H}\right.$ and $\left.{ }^{13} \mathrm{C}\right)$ were recorded at $25{ }^{\circ} \mathrm{C}$ on NMR Avance 600 spectrometer (Bruker, Germany) at 300 and $150 \mathrm{MHz}$ for ${ }^{1} \mathrm{H}$ and ${ }^{13} \mathrm{C}$ nuclei, respectively. 
Chemical shifts $(\delta)$ are reported in parts per million (ppm) using tetramethylsilane as reference in the ${ }^{1} \mathrm{H}$ and the DMSO residual peak as reference in the ${ }^{13} \mathrm{C}$ spectra $(39.51 \mathrm{ppm})$. Coupling constants $(J)$ are reported in Hertz $(\mathrm{Hz})$. Mass spectra were recorded on HPLC-MS/MS (HPLC, Agilent Technologies 1200 Series; MS, Agilent Technologies 6410 Triple Quad). Mass determination was realized using electron spray ionization (ESI) in positive or negative mode. CEM Discover microwave reactor was used for microwave reactions $\left(P=150 \mathrm{~W}, t=70^{\circ} \mathrm{C}\right)$. Elemental analyses were performed on a CHNS LECO analyzer (LECO Corporation, USA). Found values for carbon, hydrogen and nitrogen were within $\pm 0.4 \%$ of the theoretical values. All compounds were routinely checked by TLC with Merck silica gel 60F-254 glass plates using the following solvent systems: petrolether/ethyl acetate/methanol 30:10:5, cyclohexane/ethyl $\begin{array}{llll}\text { acetate } & 1: 1, \quad \text { cyclohexane/ } \quad \text { dichloromethane/methanol 10:18:2, }\end{array}$ dichloromethane/dichloromethane/methanol 97:3 and 95:5. Spots were visualized by short-wave UV light and iodine vapour. Column chromatography was performed on silica gel $0.063-0.200$ $\mathrm{mm}$ (Kemika, Croatia) and 0.040-0.063 mm (Merck, Germany), with the same eluents used in TLC.

$1 H$-benzo $[d][1,2,3]$ triazole $(\mathrm{BtH})$, triphosgene, triethylamine (TEA), hydrazine hydrate, Lleucine, D-phenylglycine, DL- $p$-chlorophenylglycine, $p$-bromoaniline and $N$-methyl-1,1diphenylmethanamine were purchased from Sigma-Aldrich. Primaquine, diphenylmethanamine and (4-chlorophenyl)(phenyl)methanamine were prepared from commercially available salts (Sigma-Aldrich) prior the use. All reactions with primaquine were run light protected. 1Benzotriazole carboxylic acid chloride $(\mathrm{BtcCl}, 6)$ was prepared according to our procedures published earlier [42,43]. 4-Methoxybenzophenone hydrazone was prepared from 4- 
methoxybenzophenone and hydrazine hydrate [44]. Primaquine derivatives 1-5 were prepared according to the previously published procedures [23-29].

\subsubsection{Btc-amino acids (7a-c): general procedure}

To a suspension of $20 \mathrm{mmol}$ of amino acid in dry dioxane $(40 \mathrm{ml})$ a solution of $1.81 \mathrm{~g}(10 \mathrm{mmol})$ $\mathrm{BtcCl}(\mathbf{6})$ in dry dioxane $(10 \mathrm{ml})$ was added dropwise. The reaction mixture was stirred overnight at room temperature. Amino acid hydrochloride was filtered off, washed with dioxane and the mother liquor was evaporated under reduced pressure. The crude products were triturated several times with hot toluene. 2-[(1H-1,2,3-benzotriazole-1-carbonyl)amino]-4-methylpentanoic acid (Btc-L-leucine, 7a) and 2-[(1H-1,2,3-benzotriazole-1-carbonyl)amino]-2-phenylacetic acid (BtcD-phenylglycine, 7b) were described in our previous paper [32], while 2-[(1H-1,2,3benzotriazole-1-carbonyl)amino]-2-(4-chlorophenyl)acetic acid (Btc-DL-p-chlorophenylglycine, 7c) is a new compound.

4.1.2.1. 2-[(1H-1,2,3-benzotriazole-1-carbonyl)amino]-2-(4-chlorophenyl)acetic acid (Btc-DL-p-chlorophenylglycine (7c)

From the reaction of $3.712 \mathrm{~g} p$-chlorophenylglycine and $1.81 \mathrm{~g}$ chloride $\mathbf{6}, 3.274 \mathrm{~g}(99 \%)$ of $7 \mathrm{c}$ was obtained; $\mathrm{mp} 127^{\circ} \mathrm{C}$ (decomp.); IR (KBr): $v_{\max } 3360,2924,2540,1750,1712,1494,1450$, 1380, 1290, 1184, 1136, 1064, 1018, 976, 932, 822, 786, 754, 732, 680, 662, 642, 624, 600, 558, $538,516,466 \mathrm{~cm}^{-1} ;{ }^{1} \mathrm{H}$ NMR (DMSO- $\left.d_{6}\right) \delta 9.63-9.62(\mathrm{~d}, J=7.21 \mathrm{~Hz}, 1 \mathrm{H}), 8.24-8.22(\mathrm{~d}, J=$ $8.35 \mathrm{~Hz}, 1 \mathrm{H}), 8.16-8.14(\mathrm{~d}, J=8.30 \mathrm{~Hz}, 1 \mathrm{H}), 7.75-7.71(\mathrm{t}, J=7.56 \mathrm{~Hz}, 1 \mathrm{H}), 7.63-7.61(\mathrm{~d}, J=$ $8.46 \mathrm{~Hz}, 2 \mathrm{H}), 7.59-7.55(\mathrm{t}, J=7.72 \mathrm{~Hz}, 1 \mathrm{H}), 7.49-7.47(\mathrm{~d}, J=8.45 \mathrm{~Hz}, 2 \mathrm{H}), 7.18-7.17(\mathrm{~d}, J=$ $7.24 \mathrm{~Hz}, 1 \mathrm{H}), 5.71-5.69(\mathrm{~d}, J=7.20 \mathrm{~Hz}, 1 \mathrm{H}) ;{ }^{13} \mathrm{C} \mathrm{NMR}$ (DMSO- $\left.d_{6}\right) \delta 170.66,148.50,145.48$, 135.76, 132.81, 131.25, 130.22, 130.14, 128.41, 125.76, 119.94, 113.38, 56.69; ESI-MS; $m / z$ 
calculated for $\mathrm{C}_{15} \mathrm{H}_{11} \mathrm{ClN}_{4} \mathrm{O}_{3}: 330.05$, found: $353.2(\mathrm{M}+23)^{+}$; calculated for $\mathrm{C}_{6} \mathrm{H}_{9} \mathrm{~N}_{3}$ : 119.12, found: $120.1(\mathrm{BtH}+1)^{+}$.

\subsubsection{Btc-amino acid chlorides (8a-c): general procedure}

A solution of $4 \mathrm{mmol}$ Btc-amino acid in $20 \mathrm{ml}$ thionyl chloride was stirred overnight at room temperature. Thionyl chloride was evaporated under reduced pressure and the residue was dissolved in dry toluene and evaporated again (several times). Crude products 8a-c were used immediately in further reactions.

\subsubsection{Btc-amino acid amides (9a-g): general procedure}

A solution of $3.4 \mathrm{mmol}$ corresponding amine or hydrazone and $4 \mathrm{mmol}$ TEA in dry toluene (20 $\mathrm{ml}$ ) was added dropwise to a solution of $4 \mathrm{mmol}$ chloride 8 in dry toluene $(30 \mathrm{ml})$. The reaction mixture was stirred $30 \mathrm{~min}$ at room temperature. TEA $\times \mathrm{HCl}$ was filtered off and mother liquor was evaporated. The residue was dissolved in ethyl acetate/1\% $\mathrm{HCl}$ mixture (1:1). The organic layer was extracted three times with $\mathrm{HCl}$ solution $(w=1 \%)$, washed two times with water, dried over anhydrous sodium sulfate, filtered and evaporated under reduced pressure.

\subsubsection{2-[(1H-1,2,3-benzotriazole-1-carbonyl)amino]-N-(diphenylmethyl)-4-}

methylpentanamide $(\mathbf{9 a})$

From the reaction of $0.623 \mathrm{~g}$ diphenylmethanamine, $1.179 \mathrm{~g}$ chloride $8 \mathrm{a}$ and $0.404 \mathrm{~g}$ TEA, and after trituration with ether, $1.081 \mathrm{~g}(72 \%)$ of 9a was obtained; $\mathrm{mp} 155-158{ }^{\circ} \mathrm{C}$; $\mathrm{IR}(\mathrm{KBr}): v_{\max }$ $3328,3261,3068,2958,2929,1716,1650,1557,1522,1450,1378,1287,1230,1152,1079$, $1050,1013,925,855,836,753,699,633,567,521,462 \mathrm{~cm}^{-1} ;{ }^{1} \mathrm{H}$ NMR (DMSO-d6) $\delta 9.12-9.09$ $\left(2 \mathrm{~d}, J=3.95 \mathrm{~Hz}, 2 \mathrm{H}^{\prime}\right), 8.23-8.18(\mathrm{~m}, 2 \mathrm{H}), 7.76-7.72(\mathrm{t}, J=7.71 \mathrm{~Hz}, 1 \mathrm{H}), 7.58-7.55(\mathrm{t}, J=7.68$ 
$\mathrm{Hz}, 1 \mathrm{H}), 7.37-7.24(\mathrm{~m}, 10 \mathrm{H}), 6.18-6.16(\mathrm{~d}, J=8.37 \mathrm{~Hz}, 1 \mathrm{H}), 4.71-4.65(\mathrm{~m}, 1 \mathrm{H}), 1.94-1.88(\mathrm{~m}$, 1H), 1.73-1.62 (m, 2H), 0.95-0.89 (d, $J=6.48 \mathrm{~Hz}, 6 \mathrm{H}) ;{ }^{13} \mathrm{C}$ NMR (DMSO- $\left.d_{6}\right) \delta 170.58,148.84$, $145.47,142.19,142.08,131.32,130.06,128.40,128.34,127.49,127.24,127.05,125.65,119.84$ $113.54,56.08,52.97,38.89,24.46,23.08,21.38[45]$.

4.1.4.2. 2-[(1H-1,2,3-benzotriazole-1-carbonyl)amino]-N-(diphenylmethyl)-N-methyl-2phenylacetamide $(\mathbf{9 b})$

From the reaction of $0.671 \mathrm{~g} N$-methyl-1,1-diphenylmethanamine, $1.259 \mathrm{~g}$ chloride $\mathbf{8 b}$ and 0.404 g TEA, and after purification by column chromatography (mobile phase cyclohexane/ethyl acetate/methanol 30:10:5), $0.857 \mathrm{~g}(53 \%)$ of $9 \mathrm{~b}$ was obtained; $\mathrm{mp} 82-83.5{ }^{\circ} \mathrm{C}$; IR $(\mathrm{KBr}): v_{\max }$ $3377,3032,2939,1735,1649,1490,1405,1294,1231,1081,1033,932,867,813,753,702$, $611,569,519 \mathrm{~cm}^{-1} ;{ }^{1} \mathrm{H}$ NMR (DMSO- $\left.d_{6}\right) \delta 9.16-9.14(\mathrm{~d}, J=5.97 \mathrm{~Hz}, 1 \mathrm{H}), 8.22-8.14(\mathrm{~m}, 2 \mathrm{H})$, 7.75-7.70 (t, $J=8.27 \mathrm{~Hz}, 1 \mathrm{H}), 7.54(\mathrm{~m}, 3 \mathrm{H}), 7.43-7.21(\mathrm{~m}, 11 \mathrm{H}), 7.02-6.93(\mathrm{~m}, 2 \mathrm{H}), 6.53(\mathrm{~s}$, $1 \mathrm{H}), 6.16-6.14(\mathrm{~d}, J=6.23 \mathrm{~Hz}, 1 \mathrm{H}), 2.67(\mathrm{~s}, 3 \mathrm{H}) ;{ }^{13} \mathrm{C}$ NMR (DMSO- $\left.d_{6}\right) \delta 169.24,147.40$, $145.50,138.47,138.24,135.92,131.08,130.26,128.80,128.60,128.51,128.48,128.42,128.28$, $127.51,125.71,119.97,113.28,61.00,55.58,31.69$.

4.1.4.3. 2-[(1H-1,2,3-benzotriazole-1-carbonyl)amino]- $\mathrm{N}-[(4-$ chlorophenyl)(phenyl)methyl]-2-phenylacetamide (9c)

From the reaction of $0.740 \mathrm{~g}$ (4-chlorophenyl)(phenyl)methanamine, $1.259 \mathrm{~g}$ chloride $\mathbf{8 b}$ and $0.404 \mathrm{~g}$ TEA, and after trituration with ether/petroleum ether and purification of mother liquid by column chromatography (mobile phase cyclohexane/ethyl acetate/methanol 30:10:5), $1.400 \mathrm{~g}$ (83\%) of 9c was obtained; $\mathrm{mp} 116-118.5^{\circ} \mathrm{C}$; IR (KBr): $v_{\max } 3286,3062,3032,1748,1660$, $1502,1499,1448,1380,1232,1182,1126,1094,1036,934,852,812,752,698,612,572,554$, $518,496 \mathrm{~cm}^{-1} ;{ }^{1} \mathrm{H}$ NMR (DMSO- $\left.d_{6}\right) \delta 9.41-9.39(\mathrm{t}, J=7.41 \mathrm{~Hz}, 1 \mathrm{H}), 9.03-9.01(\mathrm{~d}, J=7.14 \mathrm{~Hz}$, 
$1 \mathrm{H}), 8.23-8.21(\mathrm{~d}, J=8.29 \mathrm{~Hz}, 1 \mathrm{H}), 8.15-8.13(\mathrm{dd}, J=2.6 \mathrm{~Hz}, 8.3 \mathrm{~Hz}, 1 \mathrm{H}), 7.74-7.71(\mathrm{t}, J=7.60$ $\mathrm{Hz}, 1 \mathrm{H}), 7.61-7.60(\mathrm{~d}, J=7.81 \mathrm{~Hz}, 2 \mathrm{H}), 7.87-7.55(\mathrm{t}, J=7.91 \mathrm{~Hz}, 1 \mathrm{H}), 7.43-7.35(\mathrm{~m}, 6 \mathrm{H}), 7.32-$ $7.28(\mathrm{~m}, 2 \mathrm{H}), 7.25-7.21(\mathrm{~m}, 2 \mathrm{H}), 7.11-7.08(\mathrm{t}, J=7.37 \mathrm{~Hz}, 2 \mathrm{H}), 6.19-6.17(\mathrm{~d}, J=8.10 \mathrm{~Hz}, 1 \mathrm{H})$ 5.84-5.81 (t, $J=6.46 \mathrm{~Hz}, 1 \mathrm{H}) ;{ }^{13} \mathrm{C}$ NMR (DMSO- $\left.d_{6}\right) \delta 172.20,148.06,145.50,141.21,140.76$, $135.60,132.20,131.15,130.21,129.40,128.79,128.51,128.26,128.19,128.05,128.00,126.72$ $125.69,119.91,113.33,59.56,56.54$.

4.1.4.4. 2-[(1H-1,2,3-benzotriazole-1-carbonyl)amino]-N-(4-bromophenyl)-2-(4chlorophenyl)acetamide (9d)

From the reaction of $0.585 \mathrm{~g} p$-bromoaniline, $1.397 \mathrm{~g}$ chloride $8 \mathbf{c}$ and $0.404 \mathrm{~g}$ TEA, and after purification by column chromatography (mobile phase cyclohexane/ethyl acetate/methanol 30:10:5) and trituration with ether/petroleum ether and toluene/petroleum ether, $0.989 \mathrm{~g}(60 \%)$ of 9d was obtained; $168.5-169.5^{\circ} \mathrm{C}$; IR (KBr): $v_{\max } 3406,3232,3062,1732,1656,1600,1498$, $1452,1396,1346,1290,1218,1092,1014,930,818,778,754,724,656,628,594,540,502 \mathrm{~cm}^{-}$ ${ }^{1} ;{ }^{1} \mathrm{H}$ NMR (DMSO- $\left.d_{6}\right) \delta 10.63(\mathrm{~s}, 1 \mathrm{H}), 9.48-9.47(\mathrm{~d}, J=7.14 \mathrm{~Hz}, 1 \mathrm{H}), 8.24-8.22(\mathrm{~d}, J=8.31$ $\mathrm{Hz}, 1 \mathrm{H}), 8.16-8.14(\mathrm{~d}, J=8.33 \mathrm{~Hz}, 1 \mathrm{H}), 7.75-7.71(\mathrm{t}, J=7.55 \mathrm{~Hz}, 1 \mathrm{H}), 7.67-7.65(\mathrm{~d}, J=8.50$ $\mathrm{Hz}, 2 \mathrm{H}), 7.60-7.57(\mathrm{t}, J=7.38 \mathrm{~Hz}, 3 \mathrm{H}), 7.55-7.48(\mathrm{~m}, 4 \mathrm{H}), 5.83-5.82(\mathrm{~d}, J=7.18 \mathrm{~Hz}, 1 \mathrm{H}) ;{ }^{13} \mathrm{C}$ NMR (DMSO- $\left.d_{6}\right) \delta 167.39,148.52,145.48,137.78,135.92,133.04,131.72,131.24,130.22$, $129.80,128.62,125.77,121.47,119.95,115.62,113.39,57.58$.

4.1.4.5. 2-[(1H-1,2,3-benzotriazole-1-carbonyl)amino]-2-(4-chlorophenyl)-N(diphenylmethyl)acetamide (9e)

From the reaction of $0.623 \mathrm{~g}$ diphenylmethanamine, $1.397 \mathrm{~g}$ chloride $8 \mathrm{c}$ and $0.404 \mathrm{~g}$ TEA, and after trituration several times with ether/petroleum ether, $0.640 \mathrm{~g} \mathrm{(38 \% )}$ of $9 \mathrm{e}$ was obtained; $\mathrm{mp}$ 164.5-166.5 ${ }^{\circ} \mathrm{C}$; IR (KBr): $v_{\max } 3388,3276,3062,1732,1682,1648,1492,1448,1380,1288$, 
$1218,1094,1024,930,818,750,702,648,590,566,540 \mathrm{~cm}^{-1} ;{ }^{1} \mathrm{H}$ NMR (DMSO- $\left.d_{6}\right) \delta 9.41-$ $9.40(\mathrm{~d}, J=8.23 \mathrm{~Hz}, 1 \mathrm{H}), 9.10-9.09\left(\mathrm{~d}, J=7.29 \mathrm{~Hz}, 1 \mathrm{H}^{\prime}\right), 8.23-8.21(\mathrm{~d}, J=8.36 \mathrm{~Hz}, 1 \mathrm{H}), 8.14-$ $8.12(\mathrm{~d}, J=8.31 \mathrm{~Hz}, 1 \mathrm{H}), 7.74-7.71(\mathrm{t}, J=7.85 \mathrm{~Hz}, 1 \mathrm{H}), 7.64-7.62(\mathrm{~d}, J=8.52 \mathrm{~Hz}, 2 \mathrm{H}), 7.57-$ $7.54(\mathrm{t}, J=8.59 \mathrm{~Hz}, 1 \mathrm{H}), 7.47-7.46(\mathrm{~d}, J=8.04 \mathrm{~Hz}, 2 \mathrm{H}), 7.37-7.35(\mathrm{~m}, 2 \mathrm{H}), 7.32-7.31(\mathrm{~d}, J=$ 7.07 Hz, 2H), 7.29-7.28 (m, 1H), 7.27-7.20 (m, 3H), 7.10-7.08 (d, J = 7.01 Hz, 2H), 6.17-6.15 $(\mathrm{d}, J=8.20 \mathrm{~Hz}, 1 \mathrm{H}), 5.84-5.83(\mathrm{~d}, J=7.23 \mathrm{~Hz}, 1 \mathrm{H}) ;{ }^{13} \mathrm{C}$ NMR $\left(\right.$ DMSO- $\left.d_{6}\right) \delta 167.71,148.10$ $145.47,141.62,141.60,136.63,132.79,131.15,130.18,129.27,128.44,128.42,128.29,127.55$, $127.22,127.04,126.85,125.69,119.90,113.31,56.55,56.34$.

4.1.4.6. 2-[(1H-1,2,3-benzotriazole-1-carbonyl)amino]-2-(4-chlorophenyl)-N-[(4chlorophenyl)(phenyl)methyl]acetamide (9f)

From the reaction of $0.740 \mathrm{~g}$ (4-chlorophenyl)(phenyl)methanamine, $1.397 \mathrm{~g}$ chloride $8 \mathrm{c}$ and $0.404 \mathrm{~g}$ TEA, and after purification by column chromatography (mobile phase cyclohexane/ethyl acetate/methanol 30:10:5) and trituration with ether/petroleum ether, $0.307 \mathrm{~g}(17 \%)$ of $\mathbf{9 f}$ was obtained; mp 158-159.5 ${ }^{\circ} \mathrm{C}$; IR (KBr): $v_{\max } 3394,3279,3062,1730,1651,1492,1450,1410$, $1381,1321,1290,1219,1184,1150,1093,1017,930,828,753,702,623,563,537 \mathrm{~cm}^{-1}$. The structure of product 9 f was confirmed indirectly, by chemical derivatization to compound $\mathbf{1 0 f}$.

4.1.4.7. $\quad N$-[(4-chlorophenyl $)\left(\left\{N^{\prime}-[(4-\right.\right.$

methoxyphenyl)(phenyl)methylidene]hydrazinecarbonyl\})methyl]-1H-1,2,3-benzotriazole-1-

carboxamide $(9 \mathrm{~g})$

From the reaction of $0.769 \mathrm{~g}$ 4-methoxybenzophenone hydrazone, $1.397 \mathrm{~g}$ chloride $\mathbf{8 c}$ and 0.404 g TEA, and after purification by column chromatography (mobile phase cyclohexane/ethyl acetate/methanol 30:10:5) and trituration with ether, $1.136 \mathrm{~g}(62 \%)$ of $9 \mathrm{~g}$ was obtained; IR $(\mathrm{KBr}): v_{\max } 3373,3307,3181,3076,3049,2923,2829,1733,1676,1604,1506,1489,1443$, 
$1377,1305,1289,1256,1179,1157,1108,1089,1031,960,935,836,806,779,749,696,653$, $628,603,570,532 \mathrm{~cm}^{-1}$. The structure of product $9 \mathrm{~g}$ was confirmed indirectly, by chemical derivatization to compound $\mathbf{1 0 g}$.

\subsubsection{PQ-ureidoamides (10a-g): general procedure}

Method A: $\mathrm{NaOH}$ solution $(w=5 \%)$ was added to a solution of $1 \mathrm{mmol}$ PQ diphosphate in water

until $\mathrm{pH}$ 9-10 was reached, and PQ base was extracted four times with dichloromethane and washed with water until $\mathrm{pH}$ 7. The organic layer was dried over anhydrous sodium sulfate, filtered and evaporated under reduced pressure. PQ base and $0.5 \mathrm{mmol}$ Btc-amino acid amide 9 were mixed in dioxane and stirred overnight at room temperature, light protected. The solvent was evaporated under reduced pressure.

Method B: A suspension of $0.4 \mathrm{mmol}$ PQ diphosphate, $0.4 \mathrm{mmol}$ Btc-amino acid amide $\mathbf{9 b}$ and $0.8 \mathrm{mmol}$ TEA in dichloromethane $(3 \mathrm{~mL})$ was heated at $70{ }^{\circ} \mathrm{C}$ in microwave reactor for $45 \mathrm{~min}$. The solvent was removed under reduced pressure. The residue was dissolved in ethyl acetate $/ 5 \%$ $\mathrm{NaOH}$ mixture (1:1). The organic layer was extracted with $5 \% \mathrm{NaOH}$ three times, washed with water two times, dried over anhydrous sodium sulfate, filtered and evaporated.

\subsubsection{1. $\quad N$-(diphenylmethyl)-2-[(\{4-[(6-methoxyquinolin-8-}

yl)amino]pentyl\}carbamoyl)amino]-4-methylpentanamide (10a)

Method A, from the reaction of $0.221 \mathrm{~g}$ Btc-amino acid amide 9a and $0.259 \mathrm{~g} \mathrm{PQ}$, and after purification by column chromatography (mobile phase cyclohexane/ethyl acetate/methanol $30: 10: 5)$ and trituration with ether, $0.253 \mathrm{~g}(87 \%)$ of $\mathbf{1 0 a}$ was obtained; $\mathrm{mp} 184.5-185.5^{\circ} \mathrm{C}$; IR $(\mathrm{KBr}): V_{\max } 3316,2958,1655,1624,1569,1519,1493,1454,1422,1388,1336,1290,1201$, $1167,1155,1052,1028,824,791,746,697 \mathrm{~cm}^{-1} ;{ }^{1} \mathrm{H}$ NMR (DMSO- $\left.d_{6}\right) \delta 8.89-8.87(\mathrm{~d}, J=8.53$ 
$\mathrm{Hz}, 1 \mathrm{H}), 8.52(\mathrm{~s}, 1 \mathrm{H}), 8.08-8.06(\mathrm{~d}, J=8.25 \mathrm{~Hz}, 1 \mathrm{H}), 7.43-7.40(\mathrm{~m}, 1 \mathrm{H}), 7.28-7.20(\mathrm{~m}, 10 \mathrm{H})$, $6.46(\mathrm{~s}, 1 \mathrm{H}), 6.25(\mathrm{~s}, 1 \mathrm{H}), 6.12-6.08(\mathrm{~m}, 2 \mathrm{H}), 6.04-6.03(\mathrm{~m}, 1 \mathrm{H}), 5.99-5.97(\mathrm{~d}, J=8.60 \mathrm{~Hz}, 1 \mathrm{H})$, 4.33-4.32 (q, $J=8.05 \mathrm{~Hz}, 14.91 \mathrm{~Hz}, 1 \mathrm{H}), 3.81(\mathrm{~s}, 3 \mathrm{H}), 3.60(\mathrm{~m}, 1 \mathrm{H}), 3.00(\mathrm{~m}, 2 \mathrm{H}), 1.61-1.35(\mathrm{~m}$, $7 \mathrm{H}), 1.18(\mathrm{~d}, J=3.31 \mathrm{~Hz}, 3 \mathrm{H}), 0.85-0.82(\mathrm{~m}, 6 \mathrm{H}) ;{ }^{13} \mathrm{C}$ NMR (DMSO- $\left.d_{6}\right) \delta 172.46,159.02$, $157.62,144.64,144.25,142.45,142.40,134.82,134.54,129.60,128.34,128.29,127.45,127.10$ $126.93,122.12,96.12,91.61,55.73,55.00,51.44,47.05,42.22,39.02,33.53,26.93,24.27$, 23.03, 22.01, 20.24; ESI-MS: $m / z$ calculated for $\mathrm{C}_{35} \mathrm{H}_{43} \mathrm{~N}_{5} \mathrm{O}_{3}$ : 581.34 , found: $582.2(\mathrm{M}+1)^{+}$; Anal. Calcd. for $\left(\mathrm{C}_{35} \mathrm{H}_{43} \mathrm{~N}_{5} \mathrm{O}_{3}\right): \mathrm{C}, 72.26 ; \mathrm{H}, 7.45 ; \mathrm{N}, 12.04$. Found: $\mathrm{C}, 72.50 ; \mathrm{H}, 7.47 ; \mathrm{N}, 12.09$. 4.1.5.2. $\quad N$-(diphenylmethyl)-2-[(\{4-[(6-methoxyquinolin-8yl)amino]pentyl\}carbamoyl)amino]-N-methyl-2-phenylacetamide (10b)

Method B, from the reaction of $0.190 \mathrm{~g}$ Btc-amino acid amide 9b, $0.182 \mathrm{~g}$ PQ diphosphate and $0.081 \mathrm{~g}$ TEA, and after purification by column chromatography (mobile phase cyclohexane/ethyl acetate/methanol 30:10:5) and trituration with ether, $0.084 \mathrm{~g}(34 \%)$ of $\mathbf{1 0 b}$ was obtained; $\mathrm{mp}$ 146.5-148.5 ${ }^{\circ} \mathrm{C}$; IR (KBr): $v_{\max } 3335,3060,3030,2962,2933,2863,1622,1563,1521,1495$, 1479, 1457, 1406, 1388, 1337, 1308, 1221, 1201, 1163, 1116, 1082, 1052, 1031, 1003, 971, 921, $869,823,791,769,735,720,701,678,624,608,566,467 \mathrm{~cm}^{-1} ;{ }^{1} \mathrm{H}$ NMR (DMSO-d 6 ) $\delta 8.54-$ $8.53(\mathrm{~d}, J=3.06 \mathrm{~Hz}, 1 \mathrm{H}), 8.09-8.07(\mathrm{~d}, J=7.94 \mathrm{~Hz}, 1 \mathrm{H}, 7.42-7.30(\mathrm{~m}, 9 \mathrm{H}), 7.25(\mathrm{~m}, 2 \mathrm{H}), 7.19-$ $7.13(\mathrm{~m}, 3 \mathrm{H}), 6.96(\mathrm{~s}, 1 \mathrm{H}), 6.89(\mathrm{~m}, 1 \mathrm{H}), 6.67-6.59(\mathrm{~m}, 2 \mathrm{H}), 6.46(\mathrm{~s}, 1 \mathrm{H}), 6.25-6.21(2 \mathrm{~s}, 2 \mathrm{H})$ 6.12-6.09 (d, $J=8.50 \mathrm{~Hz}, 1 \mathrm{H}), 5.77-5.75(\mathrm{~d}, J=8.11 \mathrm{~Hz}, 1 \mathrm{H}), 3.82(\mathrm{~s}, 3 \mathrm{H}), 3.61(\mathrm{~m}, 1 \mathrm{H}), 3.01$ (m, 2H), $2.65(\mathrm{~s}, 3 \mathrm{H}), 1.61-1.48(\mathrm{~m}, 4 \mathrm{H}), 1.19-1.18(\mathrm{~d}, J=5.83 \mathrm{~Hz}, 3 \mathrm{H}) ;{ }^{13} \mathrm{C}$ NMR (DMSO- $\left.d_{6}\right) \delta$ $171.34,159.00,157.07,144.63,144.24,138.81,138.62,134.80,134.51,129.58,128.66,128.56$, $128.49,128.38,128.22,127.70,127.36,122.10,96.11,91.62,60.33,54.96,54.26,47.00,39.02$, 33.52, 31.69, 26.87, 20.21; ESI-MS: $m / z$ calculated for $\mathrm{C}_{38} \mathrm{H}_{41} \mathrm{~N}_{5} \mathrm{O}_{3}$ : 615.32, found: 616.5 
$(\mathrm{M}+1)^{+}$, calculated for $\mathrm{C}_{13} \mathrm{H}_{10}{ }^{\circ+}: 166.08$, found: $166.9\left(\mathrm{C}_{13} \mathrm{H}_{10}{ }^{+{ }^{+}}\right)$; Anal. Calcd. for $\left(\mathrm{C}_{38} \mathrm{H}_{41} \mathrm{~N}_{5} \mathrm{O}_{3}\right)$ :

C, 74.12; H, 6.71; N, 11.37. Found: C, 74.39; H, 6.72; N, 11.33 .

4.1.5.3. N-[(4-chlorophenyl)(phenyl)methyl]-2-[(\{4-[(6-methoxyquinolin-8-

yl)amino]pentyl\}carbamoyl)amino]-2-phenylacetamide (10c)

Method A, from the reaction of $0.322 \mathrm{~g}(0.65 \mathrm{mmol})$ Btc-amino acid amide $9 \mathrm{c}$ and $0.259 \mathrm{~g} \mathrm{PQ}$, and after purification by column chromatography (mobile phase cyclohexane/ethyl acetate/methanol 30:10:5) and trituration with ether, $0.351 \mathrm{~g}(85 \%)$ of 10c was obtained; mp $129-131^{\circ} \mathrm{C}$; IR (KBr): $v_{\max } 3317,3255,1621,1571,1547,1518,1489,1453,1422,1386,1218$, 1157, 1090, 1051, 1029, 1014, 818, 790, $697 \mathrm{~cm}^{-1} ;{ }^{1} \mathrm{H}$ NMR (DMSO- $\left.d_{6}\right) \delta$ 9.28-9.25 (dd, $J=$ $5.74 \mathrm{~Hz}, 8.25 \mathrm{~Hz}, 1 \mathrm{H}), 8.54-8.53(\mathrm{~d}, J=4.09 \mathrm{~Hz}, 1 \mathrm{H}), 8.09-8.06(\mathrm{dd}, J=1.41 \mathrm{~Hz}, 8.27 \mathrm{~Hz}, 1 \mathrm{H})$, 7.44-7.38 (m, 4H), 7.36-7.16 (m, 9H), 7.13-7.09 (m, 2H), 6.69-6.65 (dd, $J=3.84 \mathrm{~Hz}, 8.57 \mathrm{~Hz}$ 1H), $6.48(\mathrm{~s}, 1 \mathrm{H}), 6.26-6.24(2 \mathrm{~s}, 2 \mathrm{H}), 6.12-6.07(\mathrm{~m}, 2 \mathrm{H}), 5.53-5.50(\mathrm{dd}, J=5.50 \mathrm{~Hz}, 8.37 \mathrm{~Hz}$, $1 \mathrm{H}), 3.82(\mathrm{~s}, 3 \mathrm{H}), 3.61(\mathrm{~m}, 1 \mathrm{H}), 3.01(\mathrm{~m}, 2 \mathrm{H}), 1.61-1.44(\mathrm{~m}, 4 \mathrm{H}), 1.19-1.18(\mathrm{~d}, J=6.25 \mathrm{~Hz}, 3 \mathrm{H})$; ${ }^{13} \mathrm{C}$ NMR (DMSO- $\left.d_{6}\right) \delta 170.08,159.01,157.09,144.64,144.26,141.66,141.09,140.25,134.82$, $134.53,131.75,129.60,129.37,128.75,128.51,128.35,128.21,127.52,126.92,126.58,122.13$ 96.12, 91.63, 56.39, 55.26, 55.00, 47.03, 39.02, 33.52, 26.85, 20.23; ESI-MS: $m / z$ calculated for $\mathrm{C}_{37} \mathrm{H}_{38} \mathrm{ClN}_{5} \mathrm{O}_{3}$ : 635.27; found $636.2(\mathrm{M}+1)^{+}$; Anal. Calcd. for $\left(\mathrm{C}_{37} \mathrm{H}_{38} \mathrm{ClN}_{5} \mathrm{O}_{3}\right): \mathrm{C}, 69.85 ; \mathrm{H}$, 6.02; N, 11.01. Found: C, 69.73; H, 6.00; N, 10.99 .

4.1.5.4. $\quad N-(4-b r o m o p h e n y l)-2-(4-c h l o r o p h e n y l)-2-[(\{4-[(6-m e t h o x y q u i n o l i n-8-$ yl)amino]pentyl\}carbamoyl)amino]acetamide (10d)

Method A, from the reaction of $0.242 \mathrm{~g}$ Btc-amino acid amide 9d and $0.259 \mathrm{~g} P Q$, and after purification by column chromatography (mobile phase cyclohexane/dichloromethane/methanol 10:18:2 and cyclohexane/ethyl acetate/methanol 30:10:5) and trituration with ether, $0.209 \mathrm{~g}$ 
(67\%) of 10d was obtained; $\mathrm{mp} 152-154.5^{\circ} \mathrm{C}$; IR (KBr): $v_{\max } 3335,3285,3093,3049,2961$, $2928,2857,1635,1591,1544,1517,1486,1454,1421,1388,1347,1303,1283,1218,1201$, $1157,1091,1072,1050,1028,1009,968,935,899,817,787,760,710,674,622,551,499 \mathrm{~cm}^{-1}$; ${ }^{1} \mathrm{H}$ NMR (DMSO- $\left.d_{6}\right) \delta 8.96(\mathrm{~s}, 1 \mathrm{H}), 8.54-8.53(\mathrm{~d}, J=3.87 \mathrm{~Hz}, 1 \mathrm{H}), 8.44(\mathrm{~s}, 1 \mathrm{H}), 8.09-8.06(\mathrm{~d}, J$ $=8.20 \mathrm{~Hz}, 1 \mathrm{H}), 7.53-7.46(\mathrm{~m}, 1 \mathrm{H}), 7.44-7.36(\mathrm{~m}, 6 \mathrm{H}), 7.33-7.30(\mathrm{~m}, 2 \mathrm{H}), 7.12-7.09(\mathrm{dd}, J=3.61$ $\mathrm{Hz}, 7.49 \mathrm{~Hz}, 1 \mathrm{H}), 6.47(\mathrm{~s}, 1 \mathrm{H}), 6.25(\mathrm{~s}, 1 \mathrm{H}), 6.09-6.06(\mathrm{~d}, J=8.75 \mathrm{~Hz}, 1 \mathrm{H}), 5.33-5.30(\mathrm{~d}, J=$ $7.71 \mathrm{~Hz}, 1 \mathrm{H}), 3.82(\mathrm{~s}, 3 \mathrm{H}), 3.57(\mathrm{~m}, 1 \mathrm{H}), 3.09(\mathrm{~m}, 2 \mathrm{H}), 1.51-1.40(\mathrm{~m}, 4 \mathrm{H}), 1.15-1.12(\mathrm{~d}, J=5.74$ $\mathrm{Hz}, 3 \mathrm{H}) ;{ }^{13} \mathrm{C}$ NMR (DMSO-d 6$) \delta 169.47,158.99,153.85,144.62,144.24,139.52,139.15$, $134.80,134.51,131.42,131.42,128.30,119.36,129.57,122.10,112.52,96.10,91.61,55.72$, 54.98, 46.87, 39.02, 33.27, 25.72, 20.16; ESI-MS: $\mathrm{m} / z$ calculated for $\mathrm{C}_{30} \mathrm{H}_{34} \mathrm{BrClN}_{5} \mathrm{O}_{3}$ : 625.13, found: $626.3(\mathrm{M}+1)^{+}$; Anal. Calcd. for $\left(\mathrm{C}_{30} \mathrm{H}_{31} \mathrm{BrClN}_{5} \mathrm{O}_{3}\right)$ : C, 57.66; H, 5.00; N, 11.21. Found: $\mathrm{C}$, 57.81; H, 5.02; N, 11.23.

\subsubsection{2-(4-Chlorophenyl)-N-(diphenylmethyl)-2-[(\{4-[(6-methoxyquinolin-8-}

\section{yl)amino]pentyl\}carbamoyl)amino]acetamide (10e)}

Method A, from the reaction of $0.230 \mathrm{~g}$ Btc-amino acid amide 9e and $0.259 \mathrm{~g}$ PQ, and after purification by column chromatography (mobile phase cyclohexane/ethyl acetate/methanol 30:10:5) and trituration with ether, $0.114 \mathrm{~g}(36 \%)$ of $10 \mathrm{e}$ was obtained; $\mathrm{mp} 180-183{ }^{\circ} \mathrm{C}$; IR $(\mathrm{KBr}): V_{\max } 3321,3254,1621,1572,1547,1519,1491,1455,1422,1388,1348,1218,1197$, $1159,1091,1051,1030,1013,819,790,744,693 \mathrm{~cm}^{-1} ;{ }^{1} \mathrm{H}$ NMR (DMSO- $\left.d_{6}\right) \delta 9.27-9.25(\mathrm{~d}, J=$ $8.53 \mathrm{~Hz}, 1 \mathrm{H}), 8.53-8.52(\mathrm{~d}, J=3.74 \mathrm{~Hz}, 1 \mathrm{H}), 8.08-8.06(\mathrm{dd}, J=1.46 \mathrm{~Hz}, 8.24 \mathrm{~Hz}, 1 \mathrm{H}), 7.43-$ $7.41(\mathrm{~m}, 1 \mathrm{H}), 7.39-7.31(\mathrm{~m}, 5 \mathrm{H}), 7.28-7.21(\mathrm{~m}, 5 \mathrm{H}), 7.18-7.17(\mathrm{~m}, 2 \mathrm{H}), 7.10-7.09(\mathrm{~d}, J=7.51$ $\mathrm{Hz}, 2 \mathrm{H}), 6.70-6.69(\mathrm{~d}, J=8.53 \mathrm{~Hz}, 1 \mathrm{H}), 6.47(\mathrm{~s}, 1 \mathrm{H}), 6.26-6.24(2 \mathrm{~s}, 2 \mathrm{H}), 6.11-6.10(\mathrm{~d}, J=8.70$ $\mathrm{Hz}, 1 \mathrm{H}), 6.06-6.05(\mathrm{~d}, J=8.49 \mathrm{~Hz}, 1 \mathrm{H}), 5.54-5.52(\mathrm{dd}, J=2.55 \mathrm{~Hz}, 8.52 \mathrm{~Hz}, 1 \mathrm{H}), 3.81(\mathrm{~s}, 3 \mathrm{H})$, 
3.62-3.60 (m, 1H), 3.02-2.97 (m, 2H), $1.64-1.41(\mathrm{~m}, 4 \mathrm{H}), 1.19-1.18(\mathrm{~d}, J=5.54 \mathrm{~Hz}, 3 \mathrm{H}) ;{ }^{13} \mathrm{C}$ NMR (DMSO- $\left.d_{6}\right) \delta 169.49,158.98,156.92,144.61,144.21,142.01,141.86,139.47,134.77$ $134.49,131.81,129.55,128.39,128.34,128.23,128.09,127.44,127.09,126.90,126.80,122.06$ 96.06, 91.62, 56.90, 55.70, 54.95, 47.00, 39.02, 33.47, 26.78, 20.18; ESI-MS: $m / z$ calculated for $\mathrm{C}_{37} \mathrm{H}_{38} \mathrm{ClN}_{5} \mathrm{O}_{3}$ : 635.27, found: $636.4(\mathrm{M}+1)^{+}$; Anal. Calcd. for $\left(\mathrm{C}_{37} \mathrm{H}_{38} \mathrm{ClN}_{5} \mathrm{O}_{3}\right): \mathrm{C}, 69.85 ; \mathrm{H}$, 6.02; N, 11.01. Found: C, 69.79; H, 6.01; N, 11.00.

4.1.5.6. 2-(4-Chlorophenyl)-N-[(4-chlorophenyl)(phenyl)methyl]-2-[(\{4-[(6methoxyquinolin-8-yl)amino]pentyl\}carbamoyl)amino]acetamide (10f)

Method A, from the reaction of $0.265 \mathrm{~g}$ Btc-amino acid amide 9f and $0.259 \mathrm{~g}$ PQ, and after purification by column chromatography (mobile phase cyclohexane/ethyl acetate/methanol 30:10:5) and trituration with ether, $0.127 \mathrm{~g}(38 \%)$ of $\mathbf{1 0 f}$ was obtained; $\mathrm{mp} 150-151.5^{\circ} \mathrm{C}$; IR $(\mathrm{KBr}): v_{\max } 3317,3252,1623,1519,1489,1454,1387,1218,1158,1091,1051,1013,819,790$, 757, $697 \mathrm{~cm}^{-1} ;{ }^{1} \mathrm{H}$ NMR (DMSO- $\left.d_{6}\right) \delta 9.29-9.28(\mathrm{~d}, J=8.62 \mathrm{~Hz}, 1 \mathrm{H}), 8.53(\mathrm{~s}, 1 \mathrm{H}), 8.08-8.07(\mathrm{~d}$, $J=7.19 \mathrm{~Hz}, 1 \mathrm{H}), 7.43-7.33(\mathrm{~m}, 7 \mathrm{H}), 7.31-7.23(\mathrm{~m}, 4 \mathrm{H}), 7.13-7.09(\mathrm{~m}, 2 \mathrm{H}), 6.71-6.68(\mathrm{dd}, J=$ $4.04 \mathrm{~Hz}, 8.40 \mathrm{~Hz}, 1 \mathrm{H}), 6.47$ (s, 1H), 6.26-6.24 (2s, 2H), 6.11-6.10 (d, $J=8.66 \mathrm{~Hz}, 1 \mathrm{H}), 6.07-$ $6.06(\mathrm{~d}, J=8.28 \mathrm{~Hz}, 1 \mathrm{H}), 5.53-5.50(\mathrm{dt}, J=2.30 \mathrm{~Hz}, 8.23 \mathrm{~Hz}, 1 \mathrm{H}), 3.81(\mathrm{~s}, 3 \mathrm{H}), 3.61-3.60(\mathrm{~m}$, 1H), $3.00(\mathrm{~m}, 2 \mathrm{H}), 1.63-1.42(\mathrm{~m}, 4 \mathrm{H}), 1.19-1.18(\mathrm{~d}, J=6.22 \mathrm{~Hz}, 3 \mathrm{H}) ;{ }^{13} \mathrm{C}$ NMR (DMSO- $\left.d_{6}\right) \delta$ $169.59,158.98,156.94,144.61,144.21,141.50,140.92,139.32,134.76,134.49,131.81,131.56$ $129.55,129.27,128.67,128.48,128.35,128.21,128.15,127.42,126.84,122.06,96.08,91.62$ $55.77,55.34,54.95,47.00,39.02,33.47,26.76,20.18$; ESI-MS: $\mathrm{m} / \mathrm{z}$ calculated for $\mathrm{C}_{37} \mathrm{H}_{37} \mathrm{Cl}_{2} \mathrm{~N}_{5} \mathrm{O}_{3}$ : 669.23, found: $670.4(\mathrm{M}+1)^{+}$; Anal. Calcd. for $\left(\mathrm{C}_{37} \mathrm{H}_{37} \mathrm{Cl}_{2} \mathrm{~N}_{5} \mathrm{O}_{3}\right)$ : C, 66.27; $\mathrm{H}$, 5.56; N, 10.44. Found: C, 66.40; H, 5.58; N, 10.46. 


\subsubsection{3-[(4-Chlorophenyl $)\left(\left\{N^{\prime}-[(4-\right.\right.$}

methoxyphenyl)(phenyl)methylidene]hydrazinecarbonyl\})methyl]-1-\{4-[(6-methoxyquinolin-8yl)amino]pentyl\}urea (10g)

Method A, from the reaction of $0.269 \mathrm{~g} \mathrm{Btc-amino}$ acid amide $9 \mathrm{~g}$ and $0.259 \mathrm{~g} \mathrm{PQ}$, and after purification by column chromatography (mobile phase dichloromethane/methanol 95:5 and cyclohexane/ethyl acetate $1: 1)$ and trituration with ether, $0.068 \mathrm{~g} \mathrm{(20 \% )}$ of oil product $10 \mathrm{~g}$ was obtained; IR (film): $v_{\max } 3349,2930,1633,1610,1555,1509,1454,1421,1386,1324,1304$, 1250, 1220, 1201, 1164, 1090, 1029, 959, 819, 790, 772, $697 \mathrm{~cm}^{-1} ;{ }^{1} \mathrm{H}$ NMR (DMSO- $\left.d_{6}\right) \delta 10.28$ (s, $1 \mathrm{H}), 8.54-8.53(\mathrm{~d}, J=4.08 \mathrm{~Hz}, 1 \mathrm{H}), 8.09-8.06(\mathrm{~d}, J=8.20 \mathrm{~Hz}, 1 \mathrm{H}), 7.58-7.52(\mathrm{~m}, 2 \mathrm{H}), 7.44-$ $7.24(\mathrm{~m}, 8 \mathrm{H}), 7.17-7.15(\mathrm{~m}, 2 \mathrm{H}), 7.11(\mathrm{~m}, 1 \mathrm{H}), 6.99-6.92(\mathrm{~m}, 2 \mathrm{H}), 6.74-6.71(\mathrm{~d}, J=8.38 \mathrm{~Hz}$, $1 \mathrm{H}), 6.48(\mathrm{~s}, 1 \mathrm{H}), 6.27-6.21(\mathrm{~m}, 2 \mathrm{H}), 6.13-6.10(\mathrm{~d}, J=8.71 \mathrm{~Hz}, 1 \mathrm{H}), 5.54-5.51(\mathrm{~d}, J=7.95 \mathrm{~Hz}$, $0.63 \mathrm{H}), 5.37-5.35(\mathrm{~d}, J=7.81 \mathrm{~Hz}, 0.37 \mathrm{H}), 3.82(\mathrm{~s}, 3 \mathrm{H}), 3.86-3.84(\mathrm{~d}, J=4.06 \mathrm{~Hz}, 1 \mathrm{H}), 3.78-3.76$ $(\mathrm{d}, J=5.04 \mathrm{~Hz}, 2 \mathrm{H}), 3.61(\mathrm{~m}, 1 \mathrm{H}), 3.0(\mathrm{~m}, 2 \mathrm{H}), 1.65-1.48(\mathrm{~m}, 4 \mathrm{H}), 1.21-1.19(\mathrm{~d}, J=6.05 \mathrm{~Hz}$ $3 \mathrm{H}) ;{ }^{13} \mathrm{C}$ NMR (DMSO-d $) \delta 169.45,167.10,158.99,157.00,155.00,144.62,144.24,138.90$, $134.79,134.51,132.50,131.98,130.17,129.31,129.15,129.06,128.47,128.26,127.65,129.57$, $124.27,122.09,114.60,113.77,96.09,91.62,55.21,54.97,47.0,39.02,33.48,26.78,20.20$; ESI-MS: $m / z$ calculated for $\mathrm{C}_{38} \mathrm{H}_{39} \mathrm{ClN}_{6} \mathrm{O}_{4}: 678.27$, found: $679.3(\mathrm{M}+1)^{+}$; Anal. Calcd. for $\left(\mathrm{C}_{38} \mathrm{H}_{39} \mathrm{ClN}_{6} \mathrm{O}_{4}\right): \mathrm{C}, 67.20 ; \mathrm{H}, 5.79 ; \mathrm{N}, 12.37$. Found: $\mathrm{C}, 67.39 ; \mathrm{H}, 5.80 ; \mathrm{N}, 12.40$.

\subsection{Biological evaluation}

\subsubsection{Activity against erythrocytic stage of $P$. falciparum}

In vitro activity against erythrocytic stages of drug sensitive $P$. falciparum NF54 strain was determined using a ${ }^{3} \mathrm{H}$-hypoxanthine incorporation assay [46-48]. Compounds were dissolved in 
DMSO at $10 \mathrm{mg} / \mathrm{ml}$ and added to parasite cultures incubated in RPMI 1640 medium without hypoxanthine, supplemented with HEPES (5.94 g/l), $\mathrm{NaHCO}_{3}(2.1 \mathrm{~g} / \mathrm{l})$, neomycin $(100 \mathrm{U} / \mathrm{ml})$, $\operatorname{Albumax}^{\circledR}(5 \mathrm{~g} / 1)$ and washed human red cells $\mathrm{A}^{+}$at $2.5 \%$ hematocrit $(0.3 \%$ parasitemia). Serial drug dilutions of eleven 3 -fold dilution steps covering a range from 100 to $0.002 \mu \mathrm{g} / \mathrm{ml}$ were prepared. The 96 -well plates were incubated in a humidified atmosphere at $37{ }^{\circ} \mathrm{C} ; 4 \% \mathrm{CO}_{2}, 3 \%$ $\mathrm{O}_{2}, 93 \% \mathrm{~N}_{2}$. After $48 \mathrm{~h} 50 \mu \mathrm{l}$ of ${ }^{3} \mathrm{H}$-hypoxanthine $(0.5 \mu \mathrm{Ci})$ was added to each well of the plate. The plates were incubated for a further $24 \mathrm{~h}$ under the same conditions. The plates were then harvested with a Betaplate ${ }^{\mathrm{TM}}$ cell harvester (Wallac, Switzerland), and the red blood cells transferred onto a glass fiber filter then washed with distilled water. The dried filters were inserted into a plastic foil with $10 \mathrm{ml}$ of scintillation fluid, and counted in a Betaplate ${ }^{\mathrm{TM}}$ liquid scintillation counter (Wallac). $\mathrm{IC}_{50}$ values were calculated from sigmoidal inhibition curves by linear interpolation between two neighboring points [49] using Microsoft Excel; see section 4.2.3 below for details and Supplementary Figure S2 for example dose-response curves.

\subsubsection{In vitro cytotoxicity on rat L6 primary cells}

Assays were performed in 96-well microtiter plates, each well containing $100 \mu 1$ of RPMI 1640 medium supplemented with $1 \% \mathrm{~L}$-glutamine $(200 \mathrm{mM})$ and $10 \%$ foetal bovine serum, and 4000 L6 cells (a primary cell line derived from rat skeletal myoblasts) [50,51]. Serial drug dilutions of eleven 3-fold dilution steps covering a range from 100 to $0.002 \mu \mathrm{g} / \mathrm{ml}$ were prepared. After 70 hours of incubation the plates were inspected under an inverted microscope to assure growth of the controls and sterile conditions. $10 \mu \mathrm{l}$ of Alamar Blue was then added to each well and the plates incubated for another 2 hours. Then the plates were read with a microplate fluorometer using an excitation wave length of $536 \mathrm{~nm}$ and an emission wave length of $588 \mathrm{~nm}$. The $\mathrm{IC}_{50}$ 
values were calculated by linear interpolation from the sigmoid dose inhibition curves [49] using SoftmaxPro software (Molecular Devices Cooperation, USA); see section 4.2.3 below for details.

\subsubsection{Antiproliferative activity on human cell lines}

The experiments were carried out on eight human cell lines, derived from different tissues-oforigin: H460 (lung carcinoma), SW620 (colon carcinoma), MCF-7 (breast adenocarcinoma), A2780 (ovarian endometroid adenocarcinoma), HCT 116 (colorectal carcinoma), HL-60 (acute promyelocytic leukemia), K562 (chronic myeloid leukemia) and Capan-1 (pancreatic adenocarcinoma). Cells were grown in DMEM or RPMI-1640 media with the addition of $10 \%$ fetal bovine serum (FBS), $2 \mathrm{mM}$ L-glutamine, $100 \mathrm{U} / \mathrm{ml}$ penicillin and $100 \mu \mathrm{g} / \mathrm{ml}$ streptomycin, and cultured as monolayers at $37{ }^{\circ} \mathrm{C}$ in a humidified atmosphere with $5 \% \mathrm{CO}_{2}$.

Cells were seeded at $2 \times 10^{4}$ to $4 \times 10^{4}$ cells/well (depending on the doubling time of a specific cell line) in a standard 96-well microtiter plates and left to attach for $24 \mathrm{~h}$. Next day, test compounds were added in five serial 10 -fold dilutions alone or in combination with 6aminonicotinamide (always at $10 \mu \mathrm{M}$ ). Working dilutions were freshly prepared on the day of testing. The final concentration of DMSO was $<0.2 \%$ which was non-toxic to cells. The cell growth rate was evaluated after 72 hours of incubation, using the MTT assay. The percentage of growth (PG) of the cell lines was calculated as described previously [34].

The $\mathrm{IC}_{50}$ values for each compound were calculated from concentration-response curves using linear regression analysis by fitting to the two concentrations that give PG values above and below the respective reference value (i.e. 50\% growth inhibition). In effect, this is a linear interpolation between the concentration points adjacent to the $\mathrm{IC}_{50}$. We examined to what extent 
the $\mathrm{IC}_{50}$ values estimated thusly match those found by fitting a non-linear logistic (Hill) equation. This revealed a strong agreement, for instance, the average difference of $\mathrm{IC}_{50}$ calculated by the two methods for compounds $\mathbf{3 b}, \mathbf{5 v}, \mathbf{1 0 e}$ and $\mathbf{1 0 f}$ (considering antimalarial activity and antiproliferative activity over $\mathrm{H} 460$ and MCF-7 cell lines) is $0.06 \mu \mathrm{M}$ units; the dose-response curves obtained with both methods of fitting are shown in Supporting Figure S2. This agreement is consistent with past recommendations to use the linear interpolation approach for finding $\mathrm{IC}_{50}$ in sigmoidal drug response curves [49]. Each test point was performed in four technical replicates. The data reported for H460, MCF-7, SW620 and A2780 cells in Table 2 were measured in at least two separate experiments (biological replicates), while the data for an extended set of cell lines (HCT 116, HL-60, K562 and Capan-1) in Supporting Table S1 represent measurements from a single experiment.

\subsection{QSAR modeling}

\subsubsection{Collection and pre-processing of $P Q$ derivatives and antimalarial activity}

The QSAR model for prediction of antimalarial activity (log IC 50 against $P$. falciparum NF54 strain) was trained using the Support Vector Machines (SVM) algorithm for regression (henceforth: support vector regression), as implemented in the LIBSVM software [52]. In this study, SVM models were trained on a set of 56 compounds (structures provided in Supporting Data) represented with 2D molecular descriptors calculated with Chemistry Development Kit (CDK) [53]. A set of 285 CDK descriptors were initially calculated, followed by the removal of descriptors with constant or missing values for all compounds, yielding 140 descriptors in total. Prior to calculation of the CDK molecular descriptors, structures were represented as SMILES 
strings and preprocessed using the Instant JChem Standardizer (with Remove fragment, Neutralize, Remove explicit hydrogens, and Dearomatize options) [54].

Out of 56 compounds in the training set, synthesis of 23 compounds were reported in our previous work [23-26], while their antimalarial activity is reported in the current paper (Table 1).

Of note, we required at least two independent experimental measurements of antimalarial activity to include the compound in our QSAR data series, therefore excluding four compounds at this stage ( $\mathbf{2 i}, \mathbf{5 c}, \mathbf{5 q}$ and $\mathbf{5 s})$; all other compounds were measured in two or three experiments (three technical replicates each).

An additional 33 compounds and the corresponding antimalarial activity measurements were collected from the studies of Kaur et al. [37-39]. Out of 88 reported compounds in total, we selected the ones occupying similar chemical space to our compounds, as determined by Principal Component Analysis (PCA); bounding box on principal components 1 and 2 is shown in Figure S3. Among the compounds of Kaur et al., there are several stereoisomers which cannot be differentiated with 2D CDK molecular descriptors we used, therefore, we collapsed such stereoisomers into a single molecule (without stereochemistry) whose antimalarial activity was set to the mean activity of the stereoisomers. The PCA bounding box filtering and unification of stereoisomers yielded total of 33 compounds. The antimalarial activity of our compounds was measured against the P. falciparum NF54 strain (as described in 2.2.1), while Kaur et al. reported antimalarial activity against two strains of $P$. falciparum (D6 and W2) and we used the mean activity $\left(\log \mathrm{IC}_{50}\right)$ across these two strains, which is very highly correlated between the strains $\left(\mathrm{R}^{2}=0.931\right.$ across the Kaur et al. compounds). To ensure compatibility of $\log \mathrm{IC}_{50}$ values, the activities of compounds reported by Kaur et al. were converted to molar concentrations; 
following that, the salts were removed from compound molecular structures prior to calculating the molecular descriptors.

\subsubsection{Using support vector machines regression to prioritize candidate compounds}

As recommended by LIBSVM authors, the radial basis function (RBF, or Gaussian) kernel was used and the regularization parameters were optimized in a grid search procedure (C from $2^{-5}, 2^{-}$ ${ }^{4}, \ldots, 2^{20}$ and $\gamma$ from $2^{-15}, 2^{-14}, \ldots, 2^{5}$ ) [55]. The models were evaluated by using 10 -fold cross validation which was repeated 10 times with different random initialization. The model with the highest $R^{2}$, having $R^{2}=0.785$ and $\mathrm{RMSE}=0.284$ was obtained for $\mathrm{C}=2^{5}$ and $\gamma=2^{-9}$, however we retained the model with very similar predictive performance $\left(R^{2}=0.776\right.$, RMSE $=0.294$; Figure 2a), but more favorable parameter settings $\left(C=2^{1}\right.$ and $\left.\gamma=2^{-6}\right)$ for further prediction. Namely, lower values of the SVM regularization parameters C and $\gamma$ are known to result in simpler, more parsimonious models (typically evident in less non-linearity and in a smaller number of support vectors), which are less likely to overfit to training data, thus generalizing better to unseen compounds. To estimate the predictive ability on out-of-sample data, the predictions of the SVM model were evaluated against an independent set of 37 compounds whose antimalarial activity was experimentally determined in this work post-QSAR analysis (Tables 1 and S2, compounds 1a-k, 2h, 4a-k, 5i-m, 5p, 5r; compounds were originally reported in references [26,28,29], and additionally the novel compounds 10a-g reported here, see below), showing agreement with the measured activities $\left(R^{2}=0.423\right.$, RMSE $=0.403$; Figure $\left.2 \mathrm{~b}\right)$. The model was applied to infer the antimalarial activity of an in-house virtual library of 522 compounds (structures provided in Supporting Data) in order to prioritize chemical synthesis of novel PQ derivatives 10a-g. Given the strong predicted antimalarial activity (Figure 2c), 
ureidoamides 10a-g were selected for synthesis and evaluation for activity against $P$. falciparum and toxicity to mammalian cell lines.

\subsubsection{Predicting antimalarial activity for a comprehensive set of $P Q$-like compounds}

Further, we aimed to create a comprehensive QSAR model, therefore supplementing the initial training set of 56 compounds with the 37 additional PQ-related compounds (see above). After repeating the same SVM training and parameter optimization procedure on these 93 compounds, we obtained an accurate regression model (cross-validation $R^{2}=0.729$, RMSE $=0.312$; while using parameters $\mathrm{C}=2^{5}, \gamma=2^{-7}$ ). The updated 93-compound SVM model was then applied to predict the antimalarial activity of a large set of compounds extracted from PubChem database [56] (Supporting Information) that were within the applicability domain of our model. We ensured this in the following manner: for each compound from the training set, we extracted compounds from PubChem similar to it (querying for Tanimoto score $\geq 0.85$, via the PubChem API; duplicates were excluded). Furthermore, the compounds were projected to the same PC coordinates as reported in Figure S3 and filtered using the same PCA bounding box approach, yielding 13401 compounds in total. In addition to predictions of antimalarial activity for these 13401 compounds, we also provide predictions of their cytotoxicity based on cell line screening data (Supporting Information; Figure S1); see below for details.

To develop a model for prediction of cytotoxicity, the NCI-60 cancer cell line screening database was used [57]. As a measure of cytotoxicity, we used the median of compound's activities (expressed as $-\log \mathrm{IC}_{50}$ ) across the 60 cell lines. We considered only compounds with median $>$ 4 (i.e., a value assigned if no activity was detected with maximal concentration tested for a given compound). Furthermore, to ensure the applicability of the cytotoxicity model to our data, only 
compounds from NCI-60 that are close in chemical space to our compounds were considered. To this end, for each molecule from our dataset, its $k$ nearest neighbors in NCI-60 were selected (excluding identical molecules), considering $k \in\{20,50,75,100\}$. For the final model, $k=75$ was used since it yielded the best cross-validation performance $\left(R^{2}=0.514\right)$, resulting in 9301 compounds in total. Compounds were represented with 2D CDK molecular descriptors and SVM model was trained following the same procedure as described above.

To select the most important molecular descriptors in prediction of antimalarial activity, we used a forward feature selection scheme employing an SVM. The full data set containing $140 \mathrm{CDK}$ descriptors was divided into data sets containing single descriptors and evaluated according to the cross-validation scheme as described above. The Pearson correlation coefficient was a measure of relevance for the descriptor. Top 15 descriptors obtained in this way are reported in Figure S4, while the complete list is provided in Table S2.

The schematic representation of the QSAR modeling pipeline of this study is reported in Supporting Figure S5.

Supporting information. The Supporting Information and Supporting Data are available via the journal website.

Supporting Information: A comprehensive QSAR model for antimalarial activity and cytotoxicity of PQ-like compounds; IC 50 values for HCT 116, HL-60, K562 and Capan-1 human cell lines; Plot of the antimalarial activity and cytotoxicity for 13401 compounds extracted from the PubChem database; Comparison of the growth inhibition curves fitted with non-linear logistic regression and linear interpolation; Plot of the first two principal component of PCA analysis performed on 2D CDK molecular descriptors of the compounds reported by our group 
and compounds collected from the studies of Kaur et al; The 15 most informative single descriptors for antimalarial activity prediction in a SVM model; The cross-validation performance of individual CDK descriptors in a forward feature selection scheme employing SVM; The schematic representation of the QSAR modeling pipeline; Analytical and spectral data of the prepared compounds; ${ }^{1} \mathrm{H}$ and ${ }^{13} \mathrm{C}$ NMR spectra of the prepared compounds; Copies of $\mathrm{IR},{ }^{1} \mathrm{H}$ and ${ }^{13} \mathrm{C}$ NMR, and MS spectra of new compounds; Atom assignation of compounds $7 \mathbf{c}$, 9a-g and 10a-g (PDF).

Supporting Data: SMILES codes for all compounds: SVM training set (56 compounds); In house library (522 compounds); Compounds from PubChem predicted to be more active and less toxic than primaquine (199 compounds); Complete list of primaquine-like compounds retrieved from PubChem (13 401 compounds) (XLSX).

\title{
Acknowledgment
}

We acknowledge the financial support of Croatian Science Foundation via projects IP-09-20141501 ("PVSderivatives") to BZ and IP-2013-5660 ("MultiCaST") to MK. FS and JL are supported by IRB Barcelona core funding, ERC StG 757700 (“HYPER-INSIGHT") and the Ramon y Cajal fellowship of the Spanish Ministry of Economy, Industry and Competitiveness. We sincerely thank Prof. Dominique Schols for a part of cytostatic activity evaluation (Table S1).

\begin{abstract}
Abbreviations
6-AN, 6-aminonicotinamide; AD, applicability domain; CDK, chemistry development kit; ESI, electron spray ionization; FBS, fetal bovine serum; G6PD, glucose-6-phosphate dehydrogenase;
\end{abstract}


$\mathrm{IC}_{50}$, the concentration of the tested compound necessary for $50 \%$ growth inhibition; PCA, principal component analysis; PG, percentage of growth; PQ, primaquine; QSAR, quantitativestructure activity relationship; RMSE, root mean squared error; SI, selectivity index; SMP3, Stuart Melting Point; SVM, support vector machines.

\section{References}

[1] World Malaria Report 2016, (2016). http://www.who.int/malaria/publications/worldmalaria-report-2016/report/en/ (accessed January 14, 2018).

[2] T.L. Lemke, D.A. Williams, V.F. Roche, S.W. Zito, Foye's principles of medicinal chemistry, 6th ed., Wolters Kluwer (Health)/Lippincott Williams \& Wilkins, Philadelphia, 2008.

[3] L. Tilley, P. Loria, M. Foley, Chloroquine and other ouinoline antimalarials, in: Antimalar. Chemother. Mech. Action Resist. New Dir. Drug Discov., Humana Press, Totowa, NJ, 2001.

[4] N.J. White, Primaquine to prevent transmission of falciparum malaria, Lancet Infect. Dis. 13 (2013) 175-181.

[5] L. Luzzatto, G. Battistuzzi, Glucose-6-Phosphate Dehydrogenase, in: Adv. Hum. Genet. 14, Springer, Boston, MA, 1985: pp. 217-329.

[6] E.T. Nkhoma, C. Poole, V. Vannappagari, S.A. Hall, E. Beutler, The global prevalence of glucose-6-phosphate dehydrogenase deficiency: A systematic review and meta-analysis, Blood Cells. Mol. Dis. 42 (2009) 267-278. 
[7] N.J. White, L.G. Qiao, G. Qi, L. Luzzatto, Rationale for recommending a lower dose of primaquine as a Plasmodium falciparum gametocytocide in populations where G6PD deficiency is common, Malar. J. 11 (2012) 418.

[8] A.L. Peters, C.J.F. Van Noorden, Glucose-6-phosphate Dehydrogenase Deficiency and Malaria: Cytochemical Detection of Heterozygous G6PD Deficiency in Women, J. Histochem. Cytochem. 57 (2009) 1003-1011.

[9] M. Jain, S. Vangapandu, S. Sachdeva, S. Singh, P.P. Singh, G.B. Jena, K. Tikoo, P. Ramarao, C.L. Kaul, R. Jain, Discovery of a bulky 2-tert-butyl group containing primaquine analogue that exhibits potent blood-schizontocidal antimalarial activities and complete elimination of methemoglobin toxicity, J. Med. Chem. 47 (2004) 285-287.

[10] P. Gomes, M.J. Araújo, M. Rodrigues, N. Vale, Z. Azevedo, J. Iley, P. Chambel, J. Morais, R. Moreira, Synthesis of imidazolidin-4-one and 1H-imidazo[2,1-a]isoindole-2,5(3H,9bH)dione derivatives of primaquine: scope and limitations, Tetrahedron. 60 (2004) 5551-5562.

[11] P. Chambel, R. Capela, F. Lopes, J. Iley, J. Morais, L. Gouveia, J.R.B. Gomes, P. Gomes, R. Moreira, Reactivity of imidazolidin-4-one derivatives of primaquine: implications for prodrug design, Tetrahedron. 62 (2006) 9883-9891.

[12] N. Vale, M.S. Collins, J. Gut, R. Ferraz, P.J. Rosenthal, M.T. Cushion, R. Moreira, P. Gomes, Anti-Pneumocystis carinii and antiplasmodial activities of primaquine-derived imidazolidin-4-ones, Bioorg. Med. Chem. Lett. 18 (2008) 485-488.

[13] C. Sall, A.-D. Yapi, N. Desbois, S. Chevalley, J.-M. Chezal, K. Tan, J.-C. Teulade, A. Valentin, Y. Blache, Design, synthesis, and biological activities of conformationally restricted analogs of primaquine with a 1,10-phenanthroline framework, Bioorg. Med. Chem. Lett. 18 (2008) 4666-4669. 
[14] N. Vale, J. Matos, R. Moreira, P. Gomes, Amino acids as selective acylating agents: regioselective N1-acylation of imidazolidin-4-one derivatives of the antimalarial drug primaquine, Tetrahedron. 64 (2008) 11144-11149.

[15] N. Vale, J. Matos, J. Gut, F. Nogueira, V. do Rosário, P.J. Rosenthal, R. Moreira, P. Gomes, Imidazolidin-4-one peptidomimetic derivatives of primaquine: synthesis and antimalarial activity, Bioorg. Med. Chem. Lett. 18 (2008) 4150-4153.

[16] N. Vale, F. Nogueira, V.E. do Rosário, P. Gomes, R. Moreira, Primaquine dipeptide derivatives bearing an imidazolidin-4-one moiety at the $\mathrm{N}$-terminus as potential antimalarial prodrugs, Eur. J. Med. Chem. 44 (2009) 2506-2516. doi:10.1016/j.ejmech.2009.01.018.

[17] N. Vale, R. Moreira, P. Gomes, Primaquine revisited six decades after its discovery, Eur. J. Med. Chem. 44 (2009) 937-953.

[18] R. Capela, G.G. Cabal, P.J. Rosenthal, J. Gut, M.M. Mota, R. Moreira, F. Lopes, M. Prudêncio, Design and evaluation of primaquine-artemisinin hybrids as a multistage antimalarial strategy, Antimicrob. Agents Chemother. 55 (2011) 4698-4706.

[19] B. Pérez, C. Teixeira, I.S. Albuquerque, J. Gut, P.J. Rosenthal, M. Prudêncio, P. Gomes, PRIMACINS, N-cinnamoyl-primaquine conjugates, with improved liver-stage antimalarial activity, MedChemComm. 3 (2012) 1170-1172.

[20] G. Mata, V.E. do Rosário, J. Iley, L. Constantino, R. Moreira, A carbamate-based approach to primaquine prodrugs: Antimalarial activity, chemical stability and enzymatic activation, Bioorg. Med. Chem. 20 (2012) 886-892.

[21] A. Gomes, M. Machado, L. Lobo, F. Nogueira, M. Prudêncio, C. Teixeira, P. Gomes, Ncinnamoylation of antimalarial classics: effects of using acyl groups other than cinnamoyl toward dual-stage antimalarials, ChemMedChem. 10 (2015) 1344-1349. 
[22] H. Kaur, M. Machado, C. de Kock, P. Smith, K. Chibale, M. Prudêncio, K. Singh, Primaquine-pyrimidine hybrids: synthesis and dual-stage antiplasmodial activity, Eur. J. Med. Chem. 101 (2015) 266-273.

[23] G. Džimbeg, B. Zorc, M. Kralj, K. Ester, K. Pavelić, G. Andrei, R. Snoeck, J. Balzarini, E. De Clercq, M. Mintas, The novel primaquine derivatives of N-alkyl, cycloalkyl or aryl urea: Synthesis, cytostatic and antiviral activity evaluations, Eur. J. Med. Chem. 43 (2008) 1180-1187.

[24] M. Šimunović, I. Perković, B. Zorc, K. Ester, M. Kralj, D. Hadjipavlou-Litina, E. Pontiki, Urea and carbamate derivatives of primaquine: Synthesis, cytostatic and antioxidant activities, Bioorg. Med. Chem. 17 (2009) 5605-5613.

[25] I. Perković, S. Tršinar, J. Žanetić, M. Kralj, I. Martin-Kleiner, J. Balzarini, D. HadjipavlouLitina, A.M. Katsori, B. Zorc, Novel 1-acyl-4-substituted semicarbazide derivatives of primaquine - synthesis, cytostatic, antiviral and antioxidative studies, J. Enzyme Inhib. Med. Chem. 28 (2012) 601-610.

[26] K. Pavić, I. Perković, M. Cindrić, M. Pranjić, I. Martin-Kleiner, M. Kralj, D. Schols, D. Hadjipavlou-Litina, A.-M. Katsori, B. Zorc, Novel semicarbazides and ureas of primaquine with bulky aryl or hydroxyalkyl substituents: Synthesis, cytostatic and antioxidative activity, Eur. J. Med. Chem. 86 (2014) 502-514.

[27] E. Kedzierska, J. Orzelska, I. Perković, D. Knežević, S. Fidecka, M. Kaiser, B. Zorc, Pharmacological effects of primaquine ureas and semicarbazides on the central nervous system in mice and antimalarial activity in vitro, Fundam. Clin. Pharmacol. 30 (2016) 5869. 
[28] I. Perković, M. Antunović, I. Marijanović, K. Pavić, K. Ester, M. Kralj, J. Vlainić, I. Kosalec, D. Schols, D. Hadjipavlou-Litina, E. Pontiki, B. Zorc, Novel urea and bis-urea primaquine derivatives with hydroxyphenyl or halogenphenyl substituents: synthesis and biological evaluation, Eur. J. Med. Chem. 124 (2016) 622-636.

[29] K. Pavić, I. Perković, P. Gilja, F. Kozlina, K. Ester, M. Kralj, D. Schols, D. HadjipavlouLitina, E. Pontiki, B. Zorc, Design, synthesis and biological evaluation of novel primaquine-cinnamic acid conjugates of the amide and acylsemicarbazide type, Molecules. 21 (2016) 1629-1653.

[30] I. Perković, I. Butula, Z. Rajić, D. Hadjipavlou-Litina, E. Pontiki, B. Zorc, Novel ureidoamides derived from amino acids: synthesis and preliminary biological screening, Croat. Chem. Acta. 83 (2010) 151-161.

[31] I. Perković, I. Butula, B. Zorc, K. Hock, S.K. Pavelić, K. Pavelić, E.D. Clercq, J. Balzarini, M. Mintas, Novel lipophilic hydroxyurea derivatives: synthesis, cytostatic and antiviral activity evaluations, Chem. Biol. Drug Des. 71 (2008) 546-553.

[32] I. Butula, B. Zorc, V. Vela, Reactions with N-benzotriazolecarbonyl chloride. VII. Reactions with amino acids, Croat. Chem. Acta. 54 (1981) 435-440.

[33] O. Ivanciuc, Applications of Support Vector Machines in Chemistry, in: K.B. Lipkowitz, T.R. Cundari (Eds.), Rev. Comput. Chem., John Wiley \& Sons, Inc., 2007: pp. 291-400.

[34] J. Levatić, J. Ćurak, M. Kralj, T. Šmuc, M. Osmak, F. Supek, Accurate Models for P-gp Drug Recognition Induced from a Cancer Cell Line Cytotoxicity Screen, J. Med. Chem. 54 (2013) 5691-5708. 
[35] M. Gredičak, F. Supek, M. Kralj, Z. Majer, M. Hollósi, T. Šmuc, K. Mlinarić-Majerski, Š. Horvat, Computational structure-activity study directs synthesis of novel antitumor enkephalin analogs, Amino Acids. 38 (2010) 1185-1191.

[36] F. Supek, T.Š. Ramljak, M. Marjanović, M. Buljubašić, G. Kragol, N. Ilić, T. Šmuc, D. Zahradka, K. Mlinarić-Majerski, M. Kralj, Could LogP be a principal determinant of biological activity in 18-crown-6 ethers? Synthesis of biologically active adamantanesubstituted diaza-crowns, Eur. J. Med. Chem. 46 (2011) 3444-3454.

[37] K. Kaur, M. Jain, S.I. Khan, M.R. Jacob, B.L. Tekwani, S. Singh, P.P. Singh, R. Jain, Synthesis, antiprotozoal, antimicrobial, $\beta$-hematin inhibition, cytotoxicity and methemoglobin (MetHb) formation activities of bis(8-aminoquinolines), Bioorg. Med. Chem. 19 (2011) 197-210.

[38] K. Kaur, M. Jain, S. I. Khan, M. R. Jacob, B. L. Tekwani, S. Singh, P. Pal Singh, R. Jain, Extended side chain analogues of 8-aminoquinolines: Synthesis and evaluation of antiprotozoal, antimicrobial, $\beta$-hematin inhibition, and cytotoxic activities, MedChemComm. 2 (2011) 300-307.

[39] K. Kaur, M. Jain, S.I. Khan, M.R. Jacob, B.L. Tekwani, S. Singh, P.P. Singh, R. Jain, Amino acid, dipeptide and pseudodipeptide conjugates of ring-substituted 8aminoquinolines: synthesis and evaluation of anti-infective, $\beta$-haematin inhibition and cytotoxic activities, Eur. J. Med. Chem. 52 (2012) 230-241.

[40] J. Watson, W.R. Taylor, D. Menard, S. Kheng, N.J. White, Modelling primaquine-induced haemolysis in G6PD deficiency, ELife. 6 (2017) e23061.

[41] K. Baird, Origins and implications of neglect of G6PD deficiency and primaquine toxicity in Plasmodium vivax malaria, Pathog. Glob. Health. 109 (2015) 93-106. 
[42] I. Butula, M. Prostenik, V. Vela, Reactions with 1-benzotriazolecarboxylic acid chloride. 1. Synthesis of 2, 6-bis (hydroxymethyl) pyridinedicarbamates, Croat. Chem. Acta. 49 (1977) $837-842$.

[43] I. Butula, M. Jadrijević-Mladar Takač, Reactions with 1-benzotriazolecarboxylic acid chloride. VIII. Synthesis of $N$-hydroxyisocyanate derivatives, Croat. Chem. Acta. 73 (2000) $569-574$.

[44] G.R. Newkome, D.L. Fishel, Preparation of hydrazones: acetophenone ydrazone, Org. Synth. (1970) 102-103.

[45] N. Opačić, M. Barbarić, B. Zorc, M. Cetina, A. Nagl, D. Frković, M. Kralj, K. Pavelić, J. Balzarini, G. Andrei, R. Snoeck, E. De Clercq, S. Raić-Malić, M. Mintas, The novel L- and D-amino acid derivatives of hydroxyurea and hydantoins: synthesis, X-ray crystal structure study, and cytostatic and antiviral activity evaluations, J. Med. Chem. 48 (2005) 475-482.

[46] R.E. Desjardins, C.J. Canfield, J.D. Haynes, J.D. Chulay, Quantitative assessment of antimalarial activity in vitro by a semiautomated microdilution technique., Antimicrob. Agents Chemother. 16 (1979) 710-718.

[47] H. Matile, J.R.L. Pink, Plasmodium falciparum malaria parasite cultures and their use in immunology, Academic Press, San Diego, 1990.

[48] T. Ponnudurai, A.D. Leeuwenberg, J.H. Meuwissen, Chloroquine sensitivity of isolates of Plasmodium falciparum adapted to in vitro culture., Trop. Geogr. Med. 33 (1981) 50-54.

[49] W. Huber, J.C. Koella, A comparison of three methods of estimating EC50 in studies of drug resistance of malaria parasites, Acta Trop. 55 (1993) 257-261.

[50] B. Page, M. Page, C. Noel, A new fluorometric assay for cytotoxicity measurements invitro, Int. J. Oncol. 3 (1993) 473-476. 
[51] S. Ansar Ahmed, R.M. Gogal, J.E. Walsh, A new rapid and simple non-radioactive assay to monitor and determine the proliferation of lymphocytes: an alternative to $[3 \mathrm{H}]$ thymidine incorporation assay, J. Immunol. Methods. 170 (1994) 211-224.

[52] C.-C. Chang, C.-J. Lin, LIBSVM: A library for support vector machines, ACM Trans. Intell. Syst. Technol. 2 (2011) 27:1-27:27.

[53] C. Steinbeck, Y. Han, S. Kuhn, O. Horlacher, E. Luttmann, E. Willighagen, The Chemistry Development Kit (CDK): An Open-Source Java Library for Chemo- and Bioinformatics, J. Chem. Inf. Comput. Sci. 43 (2003) 493-500.

[54] Instant JChem 17.24.0, ChemAxon, 2017.

[55] C.-W. Hsu, C.-C. Chang, L. Chih-Jen, A Practical Guide to Support Vector Classification, (2010).

[56] S. Kim, P.A. Thiessen, E.E. Bolton, J. Chen, G. Fu, A. Gindulyte, L. Han, J. He, S. He, B.A. Shoemaker, J. Wang, B. Yu, J. Zhang, S.H. Bryant, PubChem substance and compound databases, Nucleic Acids Res. 44 (2016) D1202-D1213.

[57] R.H. Shoemaker, The NCI60 human tumour cell line anticancer drug screen, Nat. Rev. Cancer. 6 (2006) 813-823. 
Graphical abstract

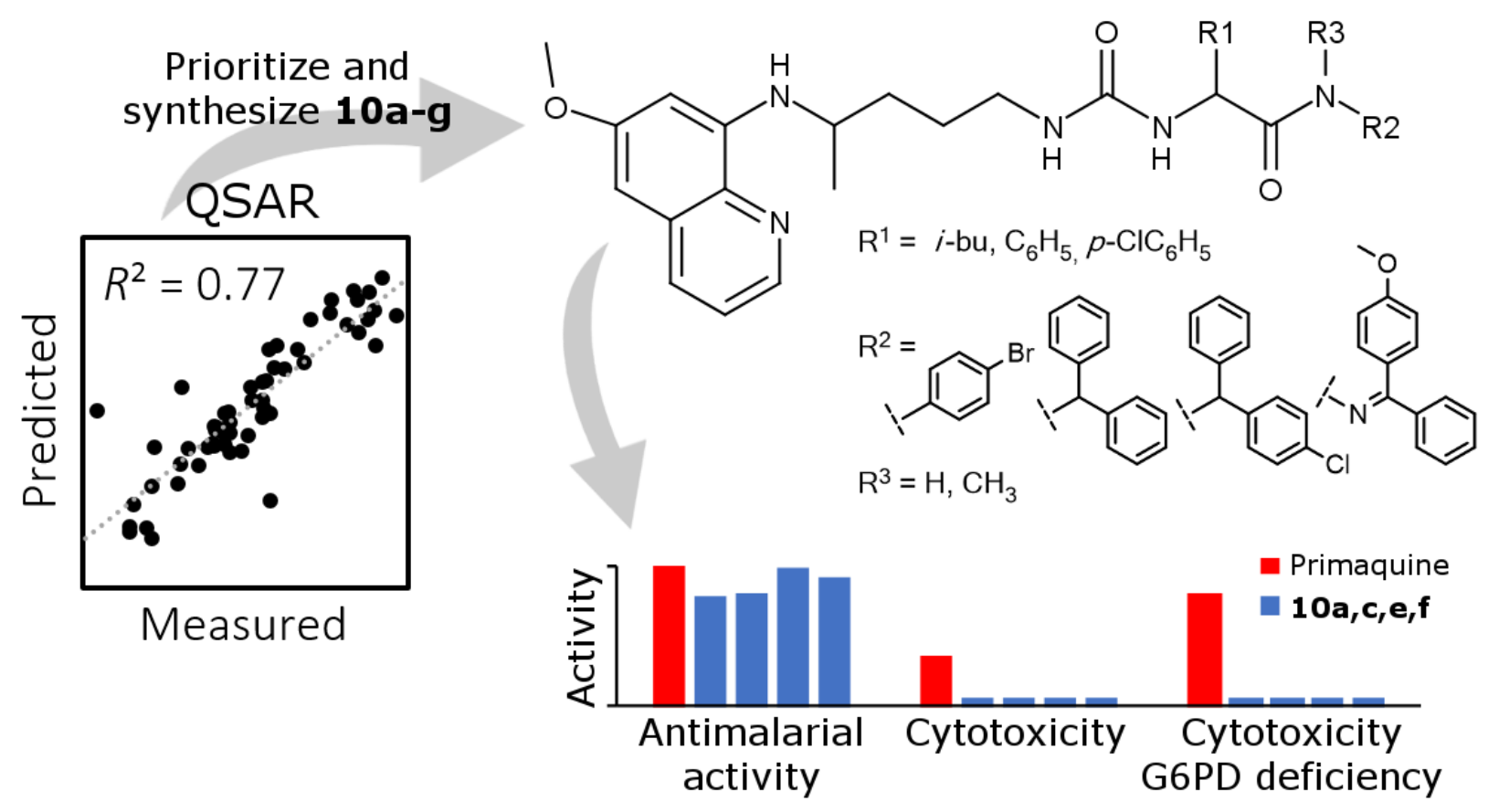



Supplementary Material - For Publication Online
Click here to download Supplementary Material -

Click here to download Supplementary Material - For Publication Online: Levatic_SupportingFigsTables_REV_FS2_JL1_FS_JL2. 西 西 (1) (1) . . . 

Supplementary Material - For Publication Online
Click here to download Supplementary Material Supplementary Material - For Publication Online
Click here to download Supplementary Material - For Publication Online: Levatic_et_al_EJMC_REVISED-FINAL_SupportingData (

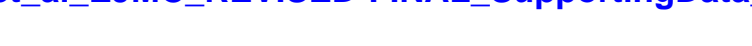


Supplementary Material - For Review Purposes Only
Click here to download Supplementary Material - For

Supplementary Material - For Review Purposes Only
Click here to download Supplementary Material - For Review Purposes Only: Levatic_spectra_REVISED-FINAL.docx

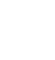

lick here to download Supplementary Material - For Review Purposes Only: Levatic_spectra_REVISED-FINAL.docx 